\title{
Dietary Polyphenols and Gene Expression in Molecular Pathways Associated with Type 2 Diabetes Mellitus: A Review
}

\author{
Gideon Gatluak Kang ${ }^{1,2}$, Nidhish Francis ${ }^{1,3}{ }^{-1}$, Rodney Hill ${ }^{2}$, Daniel Waters ${ }^{1,2}$, \\ Christopher Blanchard ${ }^{1,2}$ and Abishek Bommannan Santhakumar 1,2,*D \\ 1 Australian Research Council (ARC) Industrial Transformation Training Centre (ITTC) for Functional Grains, \\ Graham Centre for Agricultural Innovation, Wagga Wagga, NSW 2650, Australia; \\ gkang@csu.edu.au (G.G.K.); nfrancis@csu.edu.au (N.F.); dwaters@csu.edu.au (D.W.); \\ cblanchard@csu.edu.au (C.B.) \\ 2 School of Biomedical Sciences, Charles Sturt University, NSW 2650, Australia; rhill@csu.edu.au \\ 3 School of Animal and Veterinary Sciences, Charles Sturt University, NSW 2650, Australia \\ * Correspondence: asanthakumar@csu.edu.au; Tel.: +61-2-6933-2678
}

Received: 21 November 2019; Accepted: 18 December 2019; Published: 24 December 2019

\begin{abstract}
Type 2 diabetes mellitus (T2DM) is a complex metabolic disorder with various contributing factors including genetics, epigenetics, environment and lifestyle such as diet. The hallmarks of T2DM are insulin deficiency (also referred to as $\beta$-cell dysfunction) and insulin resistance. Robust evidence suggests that the major mechanism driving impaired $\beta$-cell function and insulin signalling is through the action of intracellular reactive oxygen species (ROS)-induced stress. Chronic high blood glucose (hyperglycaemia) and hyperlipidaemia appear to be the primary activators of these pathways. Reactive oxygen species can disrupt intracellular signalling pathways, thereby dysregulating the expression of genes associated with insulin secretion and signalling. Plant-based diets, containing phenolic compounds, have been shown to exhibit remedial benefits by ameliorating insulin secretion and insulin resistance. The literature also provides evidence that polyphenol-rich diets can modulate the expression of genes involved in insulin secretion, insulin signalling, and liver gluconeogenesis pathways. However, whether various polyphenols and phenolic compounds can target specific cellular signalling pathways involved in the pathogenesis of T2DM has not been elucidated. This review aims to evaluate the modulating effects of various polyphenols and phenolic compounds on genes involved in cellular signalling pathways (both in vitro and in vivo from human, animal and cell models) leading to the pathogenesis of T2DM.
\end{abstract}

Keywords: polyphenols; type 2 diabetes; pancreatic $\beta$-cell function; insulin resistance; gene expression

\section{Introduction}

In 2017, an estimated 850 billion USD of global health expenditure attributed to treatment or other health interventions for diabetes. Present estimates show that 452 million people worldwide are affected by diabetes [1]. This number is expected to rise to 693 million by 2045, raising the cost to 958 billion USD [2]. Diabetes mellitus (DM) is a complex metabolic disorder characterised by insulin deficiency (in type 1 diabetes, an autoimmune disease), and insulin resistance or insulin deficiency attributable to other pathological pathways (in type 2 diabetes).

Type 2 diabetes mellitus (T2DM) is associated with several factors including hypertension, chronic hyperglycaemia and hyperlipidaemia, resulting from insulin resistance or insulin deficiency [3]. These factors have been implicated with overproduction of reactive oxygen species (ROS) in the mitochondrial matrixes that offset cellular redox balance and induce oxidative stress [4]. Excessive 
ROS-induced oxidative stress exerts significant damage to various cellular biomolecules including lipids, proteins and DNA [5]. The resulting dysregulated expression in various genes leads to impaired insulin secretion and impaired insulin signalling. This may induce advanced complications of T2DM such as hypertension and cardiovascular diseases, collectively known as metabolic syndrome [6,7].

Plant-based products, containing polyphenols, have demonstrated remedial benefits by reversing the metabolic processes of T2DM [8]. Dietary polyphenols and phenolic compounds (Figure 1) including resveratrol, $\gamma$-oryzanol, and epicatechins have been shown to regulate the expression of genes involved in insulin secretion (e.g., Sirtuin1 [Sirt1] and glucose transporter 2 [Glut2]) in $\beta$-cells [9] and insulin signalling mechanisms (e.g., glucose transporter 4 [Glut4] and peroxisome proliferator-activated receptor gamma [PPAR $\gamma]$ ) in adipocytes [10]. Various polyphenols have also been shown to modulate the expression of insulin receptors substrate 1 (IRS-1), serine/threonine protein kinase 1 (Akt 1) and phosphoenolpyruvate carboxykinase (PEPCK) in human hepatoma cells (HEPG2) [11]. The positive effects of polyphenols on these pathways are correlated with improved $\beta$-cell function, insulin sensitivity, reduced inflammation and lipotoxicity and reduced hepatic glucose output, collectively accounting for normal glucose homeostatic function [12]. This review discusses the impact of polyphenols on regulating gene expressions in major metabolic pathways associated with the development of T2DM. Furthermore, the phenolic structures, the bioavailability and the potential mechanisms employed by polyphenols to mitigate the pathogenesis of T2DM are also discussed.

\section{Pathogenesis of Type 2 Diabetes Mellitus}

Type 2 diabetes mellitus is a multifaceted disorder with various contributing factors including genetics, epigenetics, environmental factors and lifestyle, particularly hypercaloric diets [13]. These risk factors affect the expression of genes involved in insulin secretion in $\beta$-cells and insulin sensitivity across peripheral tissues. Hyperglycaemia, a hallmark of T2DM, and hyperlipidaemia cause the overproduction of ROS and reactive nitrogen species (RNS), which then induce oxidative stress [14]. Reactive oxygen species/RNS-induced oxidative stress affects normal cellular metabolism of carbohydrates, proteins, fats and electrolytes, leading to genome and epigenome instability, cellular damage, inflammation and impaired organ function [15]. In particular, pancreatic $\beta$-cells are believed to have low endogenous antioxidant capacity, making them highly susceptible to oxidative stress [16]. Therefore, excess ROS production in $\beta$-cells leads to insufficient insulin secretion ( $\beta$-cell dysfunction). In hyperlipidaemia, triglyceride and fatty acid-induced ceramide synthesis, coupled with excess nitric oxide (NO) production, initiates $\beta$-cell apoptosis and impair insulin secretion [17].

In insulin-responsive cell types, ROS-induced oxidative stress is one of the mechanisms that disrupt insulin signalling and reduce insulin-stimulated glucose uptake in the targeted tissues such as skeletal muscle, liver and adipose. This leads to the development of insulin resistance [18]. Reduction of glucose uptake by insulin-responsive tissues leads to hyperglycaemia. In the liver, insulin resistance activates glucose production referred to as hepatic gluconeogenesis [19]. Consequently, this leads to excessive hyperglycaemia and elevated free fatty acid (FFA), furthering cellular oxidative stress-induced damages and T2DM complications [20]. However, various polyphenols have been shown to have antioxidant properties that may mitigate the adverse effects of hyperglycaemia in T2DM (Figure 2).

\section{Polyphenol Classes and Their Structures}

Polyphenols represent a diverse group of plant products widely found in vegetables, fruits, tea, coffee, cereals, chocolate, oils and various cocoa products [21,22]. The main classes of polyphenols comprise flavonoids (Figure 1) and non-flavonoids [23]. The major subclasses of flavonoids include anthocyanins, flavanones, flavones, flavonols and isoflavonoids [24]. Based on their phenolic rings and the structural elements binding the rings, dietary polyphenols are categorised into glycones (the sugar-phenolic group) and aglycones (the non-sugar group) [25]. Apart from flavanols, which are usually found as aglycones, most dietary polyphenols are glycones with the hydroxyl group conjugated by one or more sugar residues. 


\subsection{Flavonoids}

Anthocyanins are glycosides characterised by aglycone connected to a sugar through a glycosidic bond. These are classified into cyanidin, delphinidin, petunidin, peonidin, malvidin and pelargonidin (Figure 1A). Recent investigations reported that red raspberries display a high content of cyanidin-3-O-sophoroside, cyanidin-3-O-(2"-O-glucosyl) rutinoside, cyanidin-3-O-glucoside, and cyanidin-3-O-rutinoside [26].

Flavanones are the most diverse flavonoid group characterised by the presence of a chiral centre at C-2 and the absence of a C2-C3 double bond (Figure 1B). The naturally occurring flavanones in plants include C-glycosyl, hydroxy, methoxy and methylenedioxy derivatives, with the C-ring attached to the B-ring at C-2 position [27]. Flavanone glycosides comprise hesperidin, narirutin and naringin. In addition to their aglycones (isosakuranetin, hesperetin, naringenin, and eriodictyol) these are found in citrus fruits such as oranges, tangerines and tangelos [28].<smiles></smiles>

A) Anthocyanins

Cyanidin $\rightarrow \mathrm{R}_{3}=\mathrm{OH}, \mathrm{R}_{5}=\mathrm{H}$ Delphinidin $\rightarrow \mathrm{R}_{3}=\mathrm{R}_{5}=\mathrm{OH}$ Malvidin $\rightarrow \mathrm{R}_{3}=\mathrm{R}_{5}=\mathrm{OCH}_{3}$ Pelargonidin $\rightarrow \mathrm{R}_{3}=\mathrm{R}_{5}=\mathrm{H}$ Peonidin $\rightarrow \mathrm{R}=\mathrm{OCH}_{3}, \mathrm{R}_{5}=\mathrm{H}$ Petunidin $\rightarrow \mathrm{R}_{3}=\mathrm{OH}, \mathrm{R}_{5}=\mathrm{OCH}_{3}$<smiles>[R]c1ccc([C@H]2CC(=O)c3c(O)cc(O)cc3O2)cc1[R]</smiles>

B) Flavanones

Naringenin $\rightarrow \mathrm{R}_{4}=\mathrm{H}, \mathrm{R}_{5}=\mathrm{OH}$ Hesperidin $\rightarrow \mathrm{R}_{4}=\mathrm{OH}, \mathrm{R}_{5}=\mathrm{OCH}_{3}$ Eriodictyol $\rightarrow \mathrm{R}_{4}=\mathrm{R}_{5}=\mathrm{OH}$

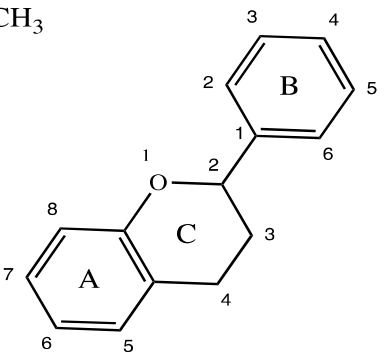

Flavonoids Backbone<smiles>[R3]c1cc(-c2oc3cc(O)cc(O)c3c(=O)c2O)cc([R3])c1O</smiles>

D) Flavonols
C) Flavones

Apigenin $\rightarrow \mathrm{R}_{3}=\mathrm{R}_{5}=\mathrm{H}$

Luteolin $\rightarrow \mathrm{R}_{3}=\mathrm{R}_{4}=\mathrm{OH}, \mathrm{R}_{5}=\mathrm{H}$

Chrysin $\rightarrow \mathrm{R}_{3}=\mathrm{R}_{4}=\mathrm{R}_{5}=\mathrm{H}$

Tricetin $\rightarrow \mathrm{R}_{3}=\mathrm{R}_{4}=\mathrm{R}_{5}=\mathrm{OH}$<smiles>[R5]c1cc([C@@H]2Oc3cc(O)cc(O)c3C[C@H]2O)cc([R3])c1[R4]</smiles>

E) Flavanols

(+)-Catechin $\rightarrow \mathrm{R}_{3}=\mathrm{H}, \mathrm{R}_{4}=\mathrm{R}_{5}=\mathrm{OH}$

(-)-Epicatechin $\rightarrow \mathrm{R}_{3}=\mathrm{R}_{4}=\mathrm{OH}, \mathrm{R}_{5}=\mathrm{H}$
Isorhamnetin $\rightarrow \mathrm{R}_{3}=\mathrm{OCH}_{3}, \mathrm{R}_{5}=\mathrm{H}$

Kaempferol $\rightarrow \mathrm{R}_{3}=\mathrm{R}_{5}=\mathrm{H}$

Myricetin $\rightarrow \mathrm{R}_{3}=\mathrm{R}_{5}=\mathrm{OH}$

Quercetin $\rightarrow \mathrm{R}_{3}=\mathrm{H}, \mathrm{R}_{5}=\mathrm{OH}$<smiles>[R20]Oc1ccc(-c2coc3cc(O)c([R2])c([R5])c3c2=O)cc1</smiles>

F) Isoflavones

Daidzein $\rightarrow \mathrm{R}_{4}=\mathrm{R}_{5}=\mathrm{R}_{6}=\mathrm{H}$

Genistein $\rightarrow \mathrm{R}_{4}=\mathrm{R}_{6}=\mathrm{H}, \mathrm{R}_{5}=\mathrm{OH}$

Glycitein $\rightarrow \mathrm{R}_{5}=\mathrm{H}, \mathrm{R}_{6}=\mathrm{OCH}_{3}, \mathrm{R}_{4}=\mathrm{H}$

Figure 1. Common structures of flavonoid classes and their derivative compounds (Chemical structures are drawn using ChemDraw software). (A) Anthocyanins; (B) Flavanones; (C) Flavones; (D) Flavonols; (E) Flavanols; (F) Isoflavones.

Flavones contain a double bond between C2 and C3, with B-ring attached at C2, as well as Oand C-glycosylation, O-methylation and hydroxylation. Except for the lack of oxygenation at C-3, flavone structures resemble flavonols and are mainly found as C-7-O-glycosides [29]. These include 
chrysin, acacetin, hispidulin and tricin (Figure 1C), which are usually found in celery, parsley, and some other herbs.

Flavonols are conjugated glucosides with sugar attachments at the 5, 7, 3', $4^{\prime}$ and $5^{\prime}$ positions (Figure 1D). They are structurally identified by a 2-phenylchromen-4-one (2-phenyl-1-benzopyran-4-one) skeleton and represented by quercetin, kaempferol, myricetin and isorhamnetin. Berry, broccoli, onion together with tea and red wine are significantly rich in quercetin-4'-O-glucoside, quercetin-3, 4'-O-diglucoside and quercetin-3-O-rutinoside [30].

The most complex subclasses of flavonoids are flavan-3-ols, structurally ranging from simple monomers to the oligomeric and the most condensed tannins. The monomeric flavan-3-ols, contain two chiral centres at C2 and C3 (Figure 1E), produce four isomers representing each level of B ring hydroxylation among which (+)-catechin and (-)-epicatechin are naturally widespread [31].

Isoflavones are distinguished by the presence of the B-ring connected at C-3 instead of C-2 position (Figure 1F). The main compounds of isoflavones include daidzein, genistein and glycitein, which are exclusively found in leguminous plants such as soybeans. They are structurally identified as 7-O-(6"-O-malonyl)glucosides, 7-O-(6"-O-acetyl)glucosides, 7-O-glucosides, or simple aglycones [32].

\subsection{Non-Flavonoids}

These include phenolic acids, stilbenes and lignans; where phenolic acids are the most common group in human diets. Phenolic acids, derived from benzoic acid and hydroxycinnamic acid, are usually conjugated with one or more $\mathrm{OH}$ in the aromatic ring. Phenolic acids formed by $\mathrm{C}_{6}$ carbon skeleton are referred to as simple phenols (e.g., thymol and phenols cresol) while the non-simple phenols may be formed by $\mathrm{C}_{6}-\mathrm{C}_{1}$ carbon configuration such as gallic, syringic and vanillic acids. Other structural formations may involve $C_{6}-C_{2}$ (e.g., phenylacetic acids and acetophenones), $C_{6}-C_{3}$ (ferulic and caffeic acids) or aldehydes (e.g., vanillin) [27]. Stilbenes are phytoalexins compounds identified by $\mathrm{C}_{6}-\mathrm{C}_{2}-\mathrm{C}_{6}$ carbon structure. These are extremely low in human diets, thus, resveratrol (3,5, $4^{\prime}$-trihdroxystilbene) is the main dietary compound identified (containing cis and trans isomers) conjugated with trans-resveatrol-3-O-glucoside (trans-piceid) derivatives. These are found in red wine, however, in very low concentrations [33]. It is argued that the major functions of phenolic compounds, such as antioxidant properties, metabolic activities and interactions with cellular receptors and enzymes, are governed by their chemical structures [34]. Additionally, the rate and extent to which these molecules are absorbed in the intestine and their bioavailability are also determined by their structural configurations [35].

\subsection{Bioavailability of Polyphenols}

Bioavailability has been referred to as the fraction of a substance, after which, when orally ingested, is absorbed and becomes available for physiological function or storage [36]. Dietary polyphenols are naturally occurring compounds found in plants and are usually consumed through foods. Before their bioactivities can be realised, polyphenols must first be absorbed, metabolised and then made available in human systems. The rate and the extent to which polyphenols are absorbed and further metabolised are influenced by several factors including their chemical structures, metabolic processing and the degree of conjugation [22]. During the course of absorption, aglycones (compounds not linked to glucose moiety) such as catechins, flavanols and flavones are absorbed in the small intestine and transported via the circulatory system into various tissues [29] where they elicit various biological effects. However, polyphenols linked to a glucose or rhamnose moiety forming ester, glycosides or polymers cannot be absorbed in their natural forms. They are usually transported to the colon and hydrolysed by gut microflora and digestive enzymes such as lactase phloridzin hydrolase (LPH) and rhamnosidases [37]. This results in the production and release of aglycones and various metabolites with diverse physiological functions [38].

Due to the nature of structural variations, the plasma concentrations of polyphenols vary greatly from one group or compound to another (Table 1). The protective properties of polyphenols depend 
on their bioavailability, thus evidence of their absorption may possibly relate to antioxidant activities in the plasma after consumption of polyphenol-rich foods [34].

Table 1. Bioavailability of polyphenols in human plasma. EGCG-epigallocatechins Gallate; EC-epicatechins; Conc.-concentration.

\begin{tabular}{cccccc}
\hline Polyphenols & Plasma Conc. $\left(\mathbf{C}_{\max }\right)$ & Half-Life $\left(\mathbf{T}_{\mathbf{1} / \mathbf{2}}\right)$ & Quantities & Food Source & Ref. \\
\hline Quercetin & $0.3-0.75 \mu \mathrm{mol} / \mathrm{L}$ & $0.6 \mathrm{~h}$ & $80-100 \mathrm{mg}$ & Onion & {$[39]$} \\
\hline EGCG and EC & $0.1-0.7 \mu \mathrm{mol} / \mathrm{L}$ & $1 \mathrm{~h}$ & $90-150 \mathrm{mg}$ & Green tea & {$[40]$} \\
\hline Epichatechin & $0.25-0.7 \mu \mathrm{mol} / \mathrm{L}$ & $2 \mathrm{~h}$ & $70-165 \mathrm{mg}$ & Cocoa & {$[41]$} \\
\hline Catechin & $0.09 \mu \mathrm{mol} / \mathrm{L}$ & $1 \mathrm{~h}$ & $35 \mathrm{mg}$ & Red wine & {$[42]$} \\
\hline Hesperetin & $1.3-2.2 \mu \mathrm{mol} / \mathrm{L}$ & $5-7 \mathrm{~h}$ & $130-220 \mathrm{mg}$ & Orange & {$[43]$} \\
\hline Naringenin & $6 \mu \mathrm{mol} / \mathrm{L}$ & $5-7 \mathrm{~h}$ & $200 \mathrm{mg}$ & Grapefruit & {$[44]$} \\
\hline Anthocyanins & $97.4 \mathrm{nmol} / \mathrm{L}$ & $1.11 \mathrm{~h}$ & $110-200 \mathrm{mg}$ & Elderberry extracts & {$[45]$} \\
\hline Lignan & $30 \mathrm{nmol} / \mathrm{L}$ & $9-24 \mathrm{~h}$ & $25 \mathrm{mg}$ & Linseed & {$[46]$} \\
\hline Isoflavones & $1.4-4 \mu \mathrm{mol} / \mathrm{L}$ & $6-8 \mathrm{~h}$ & $50 \mathrm{mg}$ & Soy & {$[47]$} \\
\hline
\end{tabular}

It has been shown that the highest concentrations measurable in plasma following the consumption of dietary-rich polyphenols are in the nanomolar (nM) range, peaking at $2-4 \mathrm{~h}$ postprandially and are then rapidly excreted [48]. Others argue this concentration may be too low to elicit a measurable biological effect [49]. However, the efficacies of phenolic bioactivities may be influenced by temporal factors such as their half-life in the circulation and other factors such as the bioactivity of their metabolic degradation products. Although the exact half-lives of polyphenols have not been precisely determined, some compounds such as anthocyanins and flavanols were shown to last 2-3 h in the plasma [50]. Epigallocatechin gallate, however, is an exception as it is usually eliminated slowly due to high levels of complexing with plasma proteins. When considering isoflavones and the lignan group, longer half-lives of 6-8 and 9-24 h, respectively, were recorded (Table 1), perhaps contributing to their potent diabetic mitigating properties. As this evidence (Table 1) suggests, maintaining physiological concentrations of polyphenols in the plasma may require frequent consumption of polyphenol-rich diets, especially for those compounds that are rapidly absorbed and excreted.

\subsection{The Proposed Mechanisms of Phenolic Action}

The diabetic mitigating properties of polyphenols have been linked to their antioxidant and anti-inflammatory capabilities, thus, making them the central focus in the early herbal medicine practices for curing diseases [51]. However, the exact mechanisms driving these properties and how polyphenols can modulate cellular signalling pathways to reverse disease processes have not yet been properly elucidated [52]. Nevertheless, some potential mechanisms have been proposed.

\subsubsection{Interaction with Cell Membrane and Receptors}

One of the important mechanisms by which polyphenols may elicit their biological effect is through initiation of cell signalling responses and interactions with both extracellular and intracellular receptors. Most polyphenols contain both hydrophilic and hydrophobic domains allowing their localisation and interactions with membrane components at different levels thereby generating cellular responses [53]. The polyphenol-membrane interaction then can induce membrane-associated functional changes such as modulation of signal transduction, ion metabolite flux, ligand-receptors interactions and membrane-associated enzymes activity [54]. For example, epigallocatechin gallate (EGCG) has been shown to regulate the activities of cell surface receptor tyrosine kinases (RTK), including insulin receptors (InsR) and insulin-like growth factor receptor (IGFR), by inhibiting tyrosine phosphatases [55,56], which in turn activates tyrosine phosphorylation and represses hepatic glucose output [57]. Furthermore, 
membrane localisation places polyphenols in close proximity with hydrosoluble and lipid-soluble radicals and as such, execute radical scavenging mechanisms [58].

Following membrane adsorption, it is claimed that polyphenols pass through membrane layers and internalise in the cytoplasm. A study on human colon adenocarcinoma cells (HT-29) demonstrated that after $15 \mathrm{~min}$ of incubation with a probed EGCG $(0.5-20 \mu \mathrm{M}), 75 \%$ of radioactively labelled EGCG was found in the cytosolic compartment with some activities also observed on the membrane fraction [59]. This indicates that polyphenols such as EGCG can directly bind to cell membrane components (lipids and proteins) and passively transfuse into the inner membrane where they interact with intracellular molecules and activate other pathways. However, other studies indicated that different phenolic compounds such as resveratrol can enter the cell through active transport, suggesting endocytosis via lipid raft [60]. This suggests that different phenolic compounds may have different mechanisms of cellular interactions based on their structural configurations.

\subsubsection{Metal Chelating Antioxidant Properties}

The antioxidant characteristics of polyphenols have primarily been attributed to their ability to regulate the production of free radicals such as RNS and ROS [61]. Some polyphenols including flavonoids are known for their metal sequestration abilities, which prevent metal-catalysed free radical formation [58]. This is due to the high affinity for metal ions of catechol moieties of the B-ring and some structural elements, such as 6,7 hydroxyl and 4-carbonyl carbonyl groups, presented in various phenolic compounds [62]. Through this binding, flavonoids can thermodynamically neutralise highly oxidising species including superoxide, peroxyl and alkoxyl free radicals [63]. This reduces the adverse effect of oxidative stress and restores cellular redox status. In addition to their free radical scavenging properties, polyphenols have been shown to play an important role in modulating the expression of genes associated with the development of type 2 diabetes.

\section{Effects of Polyphenols on Gene Modulations in T2DM}

\subsection{Polyphenols and Gene Modulations on $\beta$-Cell Dysfunction}

When considering insulin secretion pathways, the normal cellular processes leading to insulin release are regulated under tight coupling between glucose metabolites (pyruvates, citrate, malate and glutamate) and nucleotides (ATP, NADH and NADPH). Mitochondria play a focal role in linking the proximal glycolytic and distal exocytosis events [64]. The proximal glycolytic process involves a potential gradient entry of glucose molecules into the cytoplasm through glucose transporter 2 (Glut2). Glucose is further phosphorylated to produce pyruvate, which is transported into mitochondria, leading to the production of ATP [65]. During this process, ROS are produced by NADPH oxidase as by-products following electron transfer from complex II to complex III [66]. Elevated ATP raises the ATP/ADP ratio and the closure of the cellular $\mathrm{K}_{\mathrm{ATP}}$-channels, which in turn induces cell membrane depolarisation and the opening of $\mathrm{Ca}^{2+}$ channels [67]. Influx of $\mathrm{Ca}^{2+}$ increases cytosolic $\mathrm{Ca}^{2+}$ concentration, which then activates insulin exocytosis [68].

Under hyperglycaemic conditions, however, excess glucose-derived pyruvate transferred to tricarboxylic acid (TCA) cycle increases $\mathrm{NADH} / \mathrm{FADH}_{2}$ influx into the mitochondrial electron transport chain and subsequently increases ROS production [69]. In hyperlipidaemia, elevated FFA levels lead to both FFA and acetyl coenzyme A (CoA) oxidation in the TCA cycle. This increases NADH/FADH 2 donation into the electron transport chain resulting in ROS overproduction and oxidative stress. Increased levels of ROS can cause intracellular mitochondrial damage by inducing the opening of mitochondrial permeability transition and depolarisation. As a result, endogenous antioxidants leak out of mitochondria leading to mitochondrial depletion and apoptosis [70]. Mitochondrial damage reduces the ATP/ADP ratio hindering membrane depolarisation and the opening of $\mathrm{Ca}^{2+}$ channels. Consequently, this leads to delayed and insufficient insulin secretion. However, various polyphenolic compounds have been shown to neutralise oxidative stress by modulating the expression of genes 
along these pathways and thus improving insulin secretion and some of these extensively studied polyphenols are discussed further below.

Resveratrol belongs to the stilbene polyphenol group (found in grapes, berries and red wine) and possesses diverse diabetic mitigating properties. One of its major bioactivities has been implicated in improving pancreatic $\beta$-cell function and glucose homeostasis [71]. Treatment of rat insulinoma cells (INS-1E) with resveratrol $(25 \mu \mathrm{M})$ upregulated the expression of some key genes for $\beta$-cell function such as Glut2, mitochondrial transcription factor (Tfam), pancreatic and duodenal homebox 1 ( $P d x 1$ ), glucokinase (GK) and insulin 1 (Ins1) through the regulation of a master gene, Sirt1 [9]. These effects potentiated a prominent glucose-stimulated insulin secretion (GSIS) response concomitantly with increased glucose oxidation and ATP generation (Figure 2). In another study using both human (HP62) and mouse ( $\beta$-Min6) pancreatic $\beta$-cells, supplementation with resveratrol $(0.1 \mu \mathrm{M})$ and curcumin $(1$ ppm) was shown to inhibit the expression of phosphodiesterase genes (Pde3b, Pde8a and Pde10a) by activating the cAMP pathway, which then resulted in an increased insulin secretion and improved $\beta$-cell function [72]. However, data from human clinical studies have presented conflicting results. While clear diabetic inhibiting effects have not been detected in a study by Boet et al. [73], the beneficial activities of resveratrol in maintaining fasting blood glucose and reducing oxidative stress in diabetic patients has been reported by others [74]. Variation in these results may be attributed to the fact that these studies measured different parameters such as cholesterol level and other metabolic variables, suggesting resveratrol may have some specific $\beta$-cell activation properties.

Some of the flavanol compounds with potent diabetic reducing effects are catechins, which are mainly found in cocoa (Table 2). Previous studies have reported that catechins from cocoa-rich diets can attenuate $\beta$-cell mass loss and ameliorate $\beta$-cell function, by preventing oxidative stress and apoptosis in diabetic rats [75]. In a recent study using INS-1 832/13-derived $\beta$-cells, treatment with monomeric cocoa catechins $(0.25 \mu \mathrm{g} / \mathrm{mL})$ significantly increased insulin secretion by enhancing the expression of genes responsible for mitochondrial complex biogenesis such as Nuclear factor erythroid 2-related factor 2 (Nrf2) and Nrf1, and GA binding protein transcription factor alpha subunit (GABPA) [76]. In the same study, however, it was demonstrated that incubation of $\beta$-cells, INS-1 832/13, with catechins did not increase mitochondrial content or viability. This suggests that catechins-induced $\beta$-cell insulin secretion may not be due to mitochondrial population or increase in mitochondrial viability. As such, further studies are warranted to elucidate this mechanism.

Table 2. Polyphenols and gene modulations on $\beta$-cell function pathways.

\begin{tabular}{|c|c|c|c|c|c|}
\hline Polyphenols/Conc. & Genes Affected & Function & Pathways & $\begin{array}{c}\text { Cells/Tissue } \\
\text { Type }\end{array}$ & Ref. \\
\hline \multicolumn{6}{|c|}{ In vitro models } \\
\hline Resveratrol $(25 \mu \mathrm{m})$ & $\begin{array}{c}\text { SIRT1, } \uparrow \text { Glut } 2, \uparrow \\
\text { GK, } \uparrow P d x-1, \uparrow \\
H n f-1 \alpha, \uparrow \text { Tfam }\end{array}$ & $\begin{array}{c}\uparrow \text { Insulin } \\
\text { biogenesis }\end{array}$ & Mitochondrial & Cells-INS-1E & [9] \\
\hline $\begin{array}{c}\text { Resveratrol }(0.1 \mu \mathrm{M}) \\
\text { and curcumin }(1 \\
\text { PMOL/l })\end{array}$ & $\begin{array}{c}\uparrow \text { cAMP } \\
\downarrow \text { PDE } \downarrow \text { Pde3b, } \downarrow \\
P d e 8 a, \downarrow P d e 10 a\end{array}$ & $\begin{array}{l}\uparrow \text { insulin } \\
\text { secretion }\end{array}$ & $\begin{array}{l}\text { cAMP, Insulin } \\
\text { secretion }\end{array}$ & $\begin{array}{c}\text { Cells- } \beta \text {-Min6, } \\
\text { HP62 }\end{array}$ & [72] \\
\hline $\begin{array}{c}\text { Cocoa catchechins }(25 \\
\mu \mathrm{g} / \mathrm{mL})\end{array}$ & $\begin{array}{c}\uparrow H m o x 1, \uparrow \text { Nqo1, } \uparrow \\
\text { Nrf1, } \uparrow \text { GABPA, }\end{array}$ & $\begin{array}{c}\uparrow \\
\text { Mitochondrial } \\
\text { electron } \\
\text { complexes }\end{array}$ & $\begin{array}{c}\text { Electron } \\
\text { transport chain }\end{array}$ & $\begin{array}{l}\text { Cells-INS-1 } \\
832 / 13\end{array}$ & [76] \\
\hline Tyrosol $(25,50 \mu \mathrm{M} / \mathrm{mL})$ & $\begin{array}{c}\downarrow \text { GRP78, } \downarrow \text { PERK, } \downarrow \\
\text { IIF } \alpha, \downarrow C H O P \downarrow \\
\text { XBP-1, } \downarrow \text { p-JNK }\end{array}$ & $\begin{array}{l}\downarrow \text { Apoptosis, } \uparrow \\
\beta \text {-cells survival }\end{array}$ & JNK & Cells-NIT-1, & [77] \\
\hline $\begin{array}{l}\text { Jojoba seed extracts } \\
\quad(150 \mu \mathrm{g} / \mathrm{mL})\end{array}$ & $\begin{array}{c}\uparrow N f r 2, \downarrow p 22 p h o x, \downarrow \\
\text { Casp-3, } \uparrow \text { SOD \& } \\
\text { CAT }\end{array}$ & $\downarrow$ ROS/OS & Mitochondrial & Cells-RINm5f & [78] \\
\hline
\end{tabular}


Table 2. Cont.

\begin{tabular}{|c|c|c|c|c|c|}
\hline Polyphenols/Conc. & Genes Affected & Function & Pathways & $\begin{array}{l}\text { Cells/Tissue } \\
\text { Type }\end{array}$ & Ref. \\
\hline $\begin{array}{c}\gamma \text {-Oryzanol }(0.2 \text { or } 2.0 \\
\mu \mathrm{g} / \mathrm{mL})\end{array}$ & $\begin{array}{c}\downarrow \text { Dnajb9, } \downarrow \text { Xbp1s, } \downarrow \\
\text { Chop }, \downarrow \text { Casp3, } \downarrow \\
\text { CAD }\end{array}$ & $\begin{array}{c}\uparrow \beta \text {-cell } \\
\text { function, } \downarrow \text { ER } \\
\text { stress }\end{array}$ & ER Stress & Cells-MIN6 & [79] \\
\hline $\begin{array}{l}\text { Epigallocatechin } \\
\text { gallate }(1-10 \mu \mathrm{M})\end{array}$ & $\begin{array}{c}\uparrow P d x-1, \uparrow F O X O 1 \uparrow \\
\text { pAkt }\end{array}$ & $\begin{array}{c}\uparrow \text { B-cell } \\
\text { function, } \uparrow \\
\text { insulin } \\
\text { secretion }\end{array}$ & $\mathrm{pAkt} / \mathrm{Pdx}-1$ & Cells-RIN-m5F & [80] \\
\hline $\begin{array}{l}\text { Centratherum } \\
\text { anthelminticum seeds } \\
(6.25-50 \mu \mathrm{g} / \mathrm{mL})\end{array}$ & $\uparrow$ Glut2, & $\begin{array}{l}\uparrow \beta \text {-cell } \\
\text { function }\end{array}$ & $\begin{array}{l}\text { Insulin } \\
\text { secretion }\end{array}$ & Cells- $\beta$-TC6, & [81] \\
\hline \multicolumn{6}{|c|}{ In vivo model } \\
\hline $\begin{array}{c}\gamma \text {-Oryzanol }(320 \mu \mathrm{g} / \mathrm{g} \\
\text { BW) }\end{array}$ & $\begin{array}{c}\downarrow \text { Dnajb9, } \downarrow \text { Xbp } 1 s, \downarrow \\
\text { Chop, } \downarrow \text { Casp3, } \downarrow \\
\text { CAD }\end{array}$ & $\begin{array}{c}\uparrow \beta \text {-cell } \\
\text { function, } \downarrow \text { ER } \\
\text { stress }\end{array}$ & ER Stress & $\begin{array}{l}\text { Pancreaticisliets- } \\
\text { C57BL/6J mice, }\end{array}$ & [79] \\
\hline
\end{tabular}

SIRT1-Sirtuin 1; Glut2-glucose transporter 2; GK-glucokinase; Pdx-1-pancreatic and duodenal homebox 1; Hnf- $1 \alpha$-hepatocyte nuclear factor 1 alpha; Tfam-mitochondrial transcription factor A; cAMP-Cyclic adenosine $3^{\prime}, 5^{\prime}$-monophosphate; PDE-Phosphodiesterase; Hmox1-hemeoxygenase 1; Nqo1-NAD(P)H quinone oxidoreductase 1; Nrf1/Nrf2-Nuclear respiratory factor 1 and 2; GABPA-GA binding protein transcription factor alpha subunit; GRP78-78-kDa glucose-regulated protein; PERK-Protein kinase-like endoplasmic reticulum kinase; eIF $\alpha$-Inositol-requiring kinase alpha; $\mathrm{CHOP}-\mathrm{C} / \mathrm{EBP}-$ homologous protein; $\mathrm{XBP}-1-\mathrm{X}$ box binding protein 1; p-JNK-Phosphorylated c-Jun N-kinase; p22phox-Neutrophil cytochrome b $22 \mathrm{kDa}$ polypeptide; SOD-Super oxide dismutase; CAT—Catalase; Dnajb9-DnaJ homolog subfamily B member 9; Casp-3-Caspase 3; CAD—Caspase-activated DNase; FOXO1—Forkhead box O1; pAkt—Phosphorylated protein kinase A; $\uparrow$ —increased gene expression; $\downarrow$-decreased gene expression.

Tyrosol is a well-known phenolic compound found in olive oil and white wine. Previous studies have reported a potent antioxidant activity by scavenging peroxynitrite and superoxide ions relieving cellular stress [82]. In tunicamycin-induced endoplasmic reticulum (ER) stress mouse insulinoma cells (NIT-1), treatment with tyrosol ( 25 and $50 \mu \mathrm{g} / \mathrm{mL}$ for $48 \mathrm{~h}$ ) was shown to downregulate the expression of stress-related genes [binding immunoglobulin protein (BIP), inositol-requiring kinase $2 \alpha(e I F 2 \alpha)$, C/EBP-homologous protein (CHOP) and protein kinase-like endoplasmic reticulum kinase (PERK)] by inhibiting the phosphorylation of c-Jun N-kinase (JNK) pathway [77]. Thus, the ER stress inhibition properties of tyrosol enhanced insulin production by improving $\beta$-cell mass and survival.

Extracts from jojoba seed, containing a wide range of phenolic compounds, demonstrated an active free radical scavenging ability leading to improved $\beta$-cell protection [83]. A study using rat cells (RINm5f) demonstrated that jojoba seed crude extracts significantly reduced ROS levels by $69 \%$ when compared to simmondsin, the major phenolic compound found in jojoba [78]. This pattern was also reflected in caspase activation, antioxidant activity and pro-oxidant signalling pathways, where the crude extracts significantly increased the expression of $N r f 2$ while simmondsin displayed no effect. When considering p22phox, however, it was the simmondsin extracts that inhibited the activity of this gene. Nrf2 plays a key role in antioxidant defence, while p22phox activates NADPH oxidase, generating excessive ROS [84,85]. The regulation of both genes by jojoba seed extracts preserved $\beta$-cell function demonstrated by increased insulin secretion [78].

$\gamma$-Oryzanol (Orz) is another example for a structurally unique bioactive phenolic compound (featuring a mixture of ferulic acid esters and phytosterols or triterpene alcohols) exclusively found in brown rice [86]. In a similar manner to tyrosol, the diabetic healing effects of Orz have also been linked to $\beta$-cell protection against ER stress-induced apoptosis. Supplementation with Orz $(0.2$ or $2.0 \mu \mathrm{g} / \mathrm{mL})$ for $24 \mathrm{~h}$ reduced the expression of several ER stress signalling genes (ER resident DNAJ 4 (ERdj4 or Dnajb9), spliced form of $\mathrm{X}$ box binding protein 1 (Xbp1s) and $\mathrm{CHOP}$ ) and apoptosis responsive genes (caspase-3 (Casp3) and caspase-activated DNase [CAD]) in tunamycin-induced ER stress MIN6 cells [79]. This study also demonstrated that the same genes were downregulated in pancreatic islets of HFD-fed mice (C57BL/6J) treated with Orz (320 $\mu \mathrm{g} / \mathrm{g}$ body weight [BW]) for 13 weeks, which positively 
correlated with improved $\beta$-cell glucose-stimulated insulin secretion (GSIS). Surprisingly, the same study claimed that Orz did not influence some of the key genes [Pdx1, Mafa, Neorog-3 (Ngn3), Ins1 and cyclin-dependent kinase inhibitor $1 \mathrm{~A}(\mathrm{Cdkn1a)}]$ that regulate $\beta$-cell survival and proliferation, suggesting a specific anti-stress related mechanism for Orz. The different effects observed by tyrosol and Orz on the same in vitro cell culture models suggest that each bioactive compound may act through various cellular signalling pathways to regulate $\beta$-cell function.

EGCG is the most abundant polyphenol in green tea and one of the most common flavanol compounds with diverse diabetic relieving functions including improved insulin secretion via enhanced $\beta$-cell viability and glucose uptake via effective insulin signalling [80]. In rat pancreatic cells (RIN-m5F), supplementation with EGCG $(1-10 \mu \mathrm{M})$ for $2 \mathrm{~h}$ increased the expression of $P d x-1$, Forkhead box O1 (FOXO1) and protein kinase $\mathrm{B}$ (Akt) phosphorylation, resulting in augmented $\beta$-cell viability and insulin secretion [80]. This suggests $\mathrm{AKt} / \mathrm{Pdx}-1$ pathway mechanism to maintain $\beta$-cells function. Furthermore, this study demonstrated that treatment with EGCG maintained the expression of $P d x-1$ (controls mitochondrial biogenesis) for up to $72 \mathrm{~h}$ in high glucose $(33 \mathrm{mM})$ concentrations. Since EGCG is an aglycone molecule with maximum detectable plasma concentration only at $1 \mathrm{~h}$ (Table 1 ), gene modulating activities lasting for up to $72 \mathrm{~h}$ may indicate that EGCG possibly uses a positive-feedback mechanism to maintain protective effects long after its excretion.

Centratherum anthelminticum seeds are widely known for their hypoglycemic properties in treating diabetes. In an in vitro study, treatment of $\beta$-TC6 cells with $(6.25-50 \mu \mathrm{g} / \mathrm{mL})$ crude methanolic fraction of $C$. anthelminticum seeds (CAMFs) dose-dependently increased insulin secretion by enhancing the expression of Glut2, thereby improving $\beta$-cells function [81]. Looking at the in vivo effect, the same study reported that treatment of Sprague-Dawley rats with CAMFs $(50 \mathrm{mg} / \mathrm{kg}$ body weight) reduced blood glucose levels in both type 1 and type 2 diabetic subjects. When considering insulin secretion, however, it was shown that CAMFs increased insulin secretion only in type 2 diabetic rats. These findings suggest that CAMFs may offer diabetic mitigating effects only by upregulating $\beta$-cells function genes rather than $\beta$-cell preservation.

\subsection{Polyphenols and Gene Modulations on Insulin Signalling Pathways}

The processes that govern insulin signalling (in insulin-responsive tissues) involves a series of activation cascades initiated by insulin binding to its receptor resulting in tyrosine phosphorylation of insulin receptor substrates (IRSs). This, in turn, activates phosphatidylinositol 3-kinase (PI3K) followed by subsequent phosphorylation events leading to the activation of Akt and Ras-mitogen-activated protein kinase (MAPK) in insulin responsive tissue types [87]. Activation of Akt/MAPK stimulates transcription factors triggering the translocation of insulin-mediated Glut4 to the plasma membrane, of muscle and adipose tissues, thereby allowing increased glucose transport into the cell [88]. However, under hyperglycaemic and elevated FFA conditions, it is believed that overproduction of ROS activates nuclear factor kappa light chain enhancer of activated B cells (NF- $\mathrm{KB}$ ) and stress transduction pathways, such as JNK [89]. This then initiates serine phosphorylation of IRS-1 (pIRS-1(S307), thereby inhibiting Akt/PI3K activation and Glut4 translocation [90]. Consequently, this reduces insulin sensitivity and disrupts cellular glucose uptake, leading to insulin resistance.

In addition to insulin secretion activities, the diabetic reducing properties of catechins have also been related to improving insulin signalling mechanisms. In streptozocin-induced diabetic mice, three weeks of treatment with catechin $(50 \mathrm{mg} / \mathrm{kg} /$ day) significantly enhanced PI3K and the endothelial nitric oxide synthase signalling system [91]. Consequently, this increased insulin sensitivity, improved glucose uptake, lowered serum glucose levels and prevented vascular endothelial dysfunction [92].

Numerous studies have reported that sweet potato extracts (SPE) have a higher polyphenolic content associated with important antioxidant functions [93]. Quantitative in vitro investigations demonstrated that treatment of palmitate-induced insulin-resistant mouse myoblast cells (C2C12) with extracts $500 \mu \mathrm{g} / \mathrm{mL}$ and $100 \mu \mathrm{g} / \mathrm{mL}$ of orange sweet potato tubers (OSPT) and leaves (OSPL), respectively, improved glutathione (GSH) status, increased antioxidant capacity and enhanced antioxidant enzyme 
(Gpx and CAT) activities [94]. These effects were shown to directly upregulate the expression of some key genes (Glut4, Nrf1 and myocyte enhance factor 2A [Mef2a]) along the insulin signalling pathway. Glut4 is the major insulin-sensitive transporter in both skeletal muscle and adipose tissues [95], and its downregulation in glucolipotoxicity is associated with severe insulin resistance [96]. The two transcription factors, Mef2a and Nrf1, regulate the expression of Glut4 and, ultimately, glucose uptake metabolism [97]. In the same study, OSPT and OSPL also modulated the expression of carnitine palmitoyl transferase 1 (CPT1) and acetyl CoA carboxylase 2 (ACC2) genes, which are involved in the regulation of mitochondrial fatty acid oxidation and subsequently improve insulin sensitivity. Such genetic modulatory effects of sweet potato extracts indicate a remedial potential to improve insulin sensitivity in the targeted tissues.

The diabetic healing effects of plant-derived hormones (strigolactones) and stilbenoid polyphenol (pinosylvin) may be related to their ability to stimulate the SIRT1 gene under diabetic conditions. SIRT1 is a regulatory gene whose activation improves insulin sensitivity [98], mitochondrial biogenesis, energy metabolism and decreases obesity-induced inflammation [99]. Treatment of Rat L6 myoblasts with strigolactones and stilbenoid $(60-100 \mu \mathrm{M})$ for $6 \mathrm{~h}$ enhanced glucose uptake (Table 3). Strigolactones stimulated SIRT1, insulin receptor substrate 1 (IRS-1), phosphatidylinositol-3-kinase (PI3K), NRF1, Glut4 and FOXO1 translocation, thereby increasing insulin signalling sensitivity and mitochondrial biogenesis [100]. The effect of pinosylvin, in this study, was minimal at the transcription level but it stimulated the phosphorylation of AMPK, suggesting energy metabolic pathway activities.

Table 3. Polyphenols and gene modulations on insulin signalling pathways.

\begin{tabular}{|c|c|c|c|c|c|}
\hline Polyphenols/Conc. & Gene Affected & Function & Pathways & $\begin{array}{c}\text { Cells/Tissue } \\
\text { Type }\end{array}$ & Ref. \\
\hline \multicolumn{6}{|c|}{ In vitro models } \\
\hline $\begin{array}{l}\text { OSPT }(500 \mu \mathrm{g} / \mathrm{mL}) \text { and } \\
\text { OSPL }(100 \mu \mathrm{g} / \mathrm{mL})\end{array}$ & $\begin{array}{c}\uparrow \text { Glut4, } \uparrow \text { Nrf1, } \uparrow \\
\text { Mef2a, } \downarrow \text { Acc } 2 .\end{array}$ & $\begin{array}{c}\downarrow \\
\text { Hyperinsulinemia, } \\
\downarrow \text { Lipid } \\
\text { peroxidation }\end{array}$ & $\begin{array}{l}\text { Insulin } \\
\text { sensitivity }\end{array}$ & Cells-C2C12 & [94] \\
\hline $\begin{array}{l}\text { Strigolactone GR24 } \\
\text { and pinosylvin } \\
(60-100 \mu \mathrm{M})\end{array}$ & $\begin{array}{c}\uparrow S I R T 1, \uparrow \text { Glut } 4 \uparrow \\
\text { FOXO1 } \uparrow \text { IRS-1 } \uparrow \\
\text { Akt2, }\end{array}$ & $\begin{array}{c}\uparrow \text { Insulin } \\
\text { sensitivity, } \uparrow \\
\text { Glucose uptake }\end{array}$ & $\mathrm{AKt} 2$ & $\begin{array}{l}\text { Cells-L6 } \\
\text { myoblasts }\end{array}$ & [100] \\
\hline $\begin{array}{l}\text { Hibiscus sabdariffa } \\
\text { (Various dose) }\end{array}$ & $\begin{array}{l}\uparrow \text { IRS-1, } \uparrow \text { PI3K, } \downarrow \\
\text { DPP4, } \downarrow \text { GLP-1R }\end{array}$ & $\begin{array}{c}\uparrow \text { Insulin } \\
\text { sensitivity, } \downarrow \\
\text { Starch } \\
\text { breakdown }\end{array}$ & $\begin{array}{l}\text { Insulin receptor } \\
\text { activation (PI3K) }\end{array}$ & Cells-HK-2 & [101] \\
\hline $\begin{array}{l}\text { C3G and PCA } \\
(10-100 \mu \mathrm{mol})\end{array}$ & $\begin{array}{l}\uparrow \text { PPAR } \gamma, \uparrow \text { Glut4, } \uparrow \\
\text { Adiponectin }\end{array}$ & $\begin{array}{l}\uparrow \text { Glucose } \\
\text { uptake }\end{array}$ & $\operatorname{PPAR} \gamma$ & Cells-3T3-L1 & [10] \\
\hline $\begin{array}{l}\text { Rice bran extracts } \\
(10 \mu \mathrm{g} / \mathrm{mL} \text { and } 50 \mu \mathrm{g})\end{array}$ & $\begin{array}{c}\uparrow P P A R \gamma, \uparrow \\
\text { Adiponectin } \downarrow \text { TNF- } \alpha\end{array}$ & $\begin{array}{l}\uparrow \text { Insulin } \\
\text { sensitivity }\end{array}$ & $\begin{array}{c}\text { PPAR } \gamma / \\
\text { adipogenesis }\end{array}$ & Cells-3T3-L1 & [102] \\
\hline $\begin{array}{l}\text { Pigmented rice bran } \\
\text { extracts }(50 \mu \mathrm{g} / \mathrm{mL})\end{array}$ & $\begin{array}{c}\uparrow \mathrm{INSR}, \uparrow \mathrm{PI} 3 \mathrm{~K}, \uparrow \\
\text { Glut4, } \downarrow \mathrm{DDP}-4\end{array}$ & $\begin{array}{c}\uparrow \text { Insulin } \\
\text { sensitivity, } \downarrow \\
\text { Starch } \\
\text { breakdown }\end{array}$ & Akt2/PI3K & Cells-3T3-L1 & [103] \\
\hline Aspalathin $(1 \mu \mathrm{M})$ & $\begin{array}{c}\uparrow \text { Glut4, } \uparrow \mathrm{UCP} 2, \downarrow \\
\mathrm{CPT} 1, \uparrow \mathrm{Bcl}-1\end{array}$ & $\begin{array}{c}\uparrow \text { Cell viability, } \\
\uparrow \text { Insulin } \\
\text { sensitivity, } \uparrow \\
\text { Glucose uptake }\end{array}$ & pAMPK & Cells-H9c2 & [104] \\
\hline
\end{tabular}


Table 3. Cont.

\begin{tabular}{|c|c|c|c|c|c|}
\hline Polyphenols/Conc. & Gene Affected & Function & Pathways & $\begin{array}{l}\text { Cells/Tissue } \\
\text { Type }\end{array}$ & Ref. \\
\hline \multicolumn{6}{|c|}{ In vivo models } \\
\hline $\begin{array}{l}\text { Polyphenol-rich ethyl } \\
\text { acetate fraction } \\
(200 \mathrm{mg} / \mathrm{kg} \mathrm{BW})\end{array}$ & $\begin{array}{c}\uparrow \text { Insr, } \uparrow \text { IRS1, } \uparrow \text { IRS2 } \\
\uparrow \text { Akt2, } \uparrow \text { Glut4 }\end{array}$ & $\begin{array}{l}\uparrow \text { Insulin } \\
\text { sensitivity }\end{array}$ & IRS1/AKT & $\begin{array}{l}\text { Skeletal muscle- } \\
\text { Sprague- } \\
\text { Dawley rats }\end{array}$ & [105] \\
\hline $\begin{array}{l}\text { Folium Mori Extract } \\
\qquad(2 \mathrm{~g} / \mathrm{kg} \mathrm{BW})\end{array}$ & $\begin{array}{c}\uparrow \text { IRS- } 1, \uparrow \text { PI3Kp } 85 \alpha, \\
\uparrow \text { Glut- } 4\end{array}$ & $\begin{array}{l}\uparrow \text { Glucose } \\
\text { uptake }\end{array}$ & $\begin{array}{l}\text { IRS-1/PI3K/Glut-4 } \\
\text { signalling }\end{array}$ & $\begin{array}{l}\text { Skeletal muscle- } \\
\text { Sprague-Dawley } \\
\text { rats }\end{array}$ & [106] \\
\hline \multicolumn{6}{|c|}{$\begin{array}{l}\text { Glut4-Glucose transporter 4; Nrf1-Nuclear respiratory factor 1; Mef2a-Myocyte enhance factor } \\
\text { 2A; ACC2-Acetyl CoA carboxylase 2; SIRT1-Sirtuin 1; FOXO1-Forkhead box O1; IRS-1-Insulin } \\
\text { receptor substrate 1; Akt2-Protein kinase B; PI3K (p85 } \alpha \text { phosphorylated)-Phosphatidylinositol } \\
\text { 3-kinase; DPP4-Dipeptidyl-peptidase-4; GLP-1R-Glucagon-like peptide } 1 \text { receptor; PPAR } \gamma \text {-peroxisome } \\
\text { proliferator-activated receptor gamma; TNF- } \alpha \text {-Tumor necrosis factor alpha; INSR-insulin substrate receptor; } \\
\text { UCP2-uncoupling protein 2; CPT1—carnitine palmitoyltransferase-1; Bcl-1—B Cell Lymphoma 1; IRS1—insulin } \\
\text { receptor substrate 1; } \uparrow \text {-increased gene expression; } \downarrow \text {-decreased gene expression. }\end{array}$} \\
\hline
\end{tabular}

Another medicinal plant, Hibiscus sabdariffa L. calyx, has been known for its glucose-lowering ability. A study using human hepatocytes (HK-2) demonstrated that treatment with Hibiscus sabdariffa polyphenol extracts (up to $1 \mathrm{mg} / \mathrm{mL}$ ) reduced pIRS-1 (S307) phosphorylation and inhibited dipeptidyl-peptidase-4 (DPP-4) by upregulating pPI3K [101]. DPP-4 is one of the gut enzymes responsible for breaking starch down to glucose during digestion, raising glucose levels [107]. Inhibition of this enzyme suppresses postprandial hyperglycaemia, and upregulation of pPI3K improves insulin signalling mechanisms, thus alleviating insulin resistance.

Anthocyanins (ACNs) are a group of flavonoids and the most widely consumed polyphenols (with a daily intake of $180-250 \mathrm{mg} /$ day) found in fruits and berries [21]. Numerous investigations have reported diabetic reducing activities of ACN derivatives (cyanidin-3-O- $\beta$-glucoside (C3G) and protocatechuic acid (PCA)) by increasing insulin sensitivity and glucose uptake [108]. In both human and murine (3T3-L1) adipocytes, treatment with C3G and PCA $(10-100 \mu \mathrm{mol} / \mathrm{L})$ was shown to exhibit insulin-like properties by enabling Glut4 membrane translocation as well as upregulating PPAR $\gamma$ and the adiponectin gene [10]. PPAR $\gamma$ is a nuclear receptor that controls protein transcription in glucose and fatty acid uptake, whereas adiponectin, a hormone produced in adipocytes, has been referred to as an insulin sensitiser with both proteins involved in glucose and lipid metabolism [109]. Their expression, in this study, correlated with improved insulin resistance and lower blood glucose. However, inhibition of the PPAR $\gamma$ encoding gene counteracted the upregulation of Glut4 and adiponectin by anthocyanins, suggesting a direct PPAR $\gamma$ regulatory mechanisms of these genes by C3G and PCA. Although C3G demonstrated better modulatory activities, both compounds displayed similar patterns of genetic regulation in both human and murine adipocytes, more effectively at $18 \mathrm{~h}$ incubation period.

Rice brans (RB), derived from the rice milling process, contain phenolic compounds including ferulic acid, sinapic acid and protocatechuic acid [110]. Pigmented rice brans are considerably rich in anthocyanins and proanthocyanidins such as cyanidin 3-glucoside (C3G) and peonidin 3-glucoside [111]. With diverse antioxidant and glucose homeostatic capabilities, diabetic reducing effects of rice bran are well documented [112,113]. Fermented RB (FRB) extracts have been associated with antioxidant and hypoglycaemic effects in T2DM [114]. Treatment of adipocytes (3T3-L1) with FRB extracts $(10 \mu \mathrm{g} / \mathrm{mL}$ and $50 \mu \mathrm{g} / \mathrm{mL})$ for $12 \mathrm{~h}$ significantly increased the expression of PPAR $\gamma$ and adiponectin by neutralising free radicals formed by high glucose $(25 \mathrm{mM})$-induced oxidative stress [103]. The same study also demonstrated that FRB extracts inhibited the expression of tumour necrosis factor-alpha (TNF- $\alpha$ ), resulting in an increased insulin sensitivity, reduced insulin resistance and hyperglycaemia. The expression of Glut4 in this study, however, was not changed by the treatment of FRB extracts, suggesting that glucose-lowering effects of FRB extracts may not be via direct activation of Glut4 translocation. 
In contrast, pigmented rice bran extracts have demonstrated insulin-like activities both in vitro and in vivo [115]. Treatment of 3T3-L1 with $(50 \mu \mathrm{g} / \mathrm{mL})$ rice bran extracts from red and purple rice (Oryza sativa L.) for 8 and $12 \mathrm{~h}$ increased the expression of Glut4, Glut1, INSR, ISR1, Akt2 and PI3K, the key components in the insulin-signalling pathway [103]. This, consequentially, increased both insulin sensitivity and glucose uptake (Figure 2). Boue and colleagues demonstrated that pigmented rice bran extracts also inhibited the activities of key digestive enzymes (PPD-4, $\alpha$-amylase and $\alpha$-glucosidase), and this has been associated with suppressed postprandial hyperglycaemia [116]. Data from Boue and co-workers indicated that following an $8 \mathrm{~h}$ incubation, both red and purple rice bran extracts increased Akt2 expression 4.59-fold and 2.29-fold, respectively. After $12 \mathrm{~h}$, however, this expression slightly reduced to 4.1 -fold and 1.1-fold, respectively. Apart from the Akt2 gene, the modulating effects of red bran extract were optimally exhibited after a $12 \mathrm{~h}$ incubation. With the exception of Akt2 and the glucose transporters, however, purple rice bran extract was observed to be more effective at $8 \mathrm{~h}$ incubation. When considering the bioavailability of anthocyanins (Table 1), it has been shown that these compounds may only stay in circulation for up to $1.11 \mathrm{~h} \mathrm{[45].} \mathrm{Based} \mathrm{on} \mathrm{this,}$ the extended time response $(12 \mathrm{~h})$ reported by Boue and colleagues [103] suggest that other bioactive molecules may be responsible for the modulatory effects observed.

Aspalathin (ASP) derived from Aspalathus linearis is a dietary flavonoid with potent antioxidant capability and diverse diabetic inhibiting mechanisms. ASP exhibits a glucose-lowering effect comparable to metformin [117]. In rat diabetic cardiomyocytes (H9c2) exposed to $33 \mathrm{mM}$ glucose, treatment with $1 \mu \mathrm{M}$ ASP increased the expression of Glut4, ACC and uncoupling protein 2 (UCP2) by decreasing the expression of adenine monophosphate activated protein kinase threonine 172 (pAMPK (Thr172)) and CPT1 [70]. These effects concomitantly increased the level of antioxidant enzymes and anti-apoptotic genes (Bcl2/Bax ratio), which, as a result, improved cell viability, insulin sensitivity and glucose uptake.

Molineria latifolia is a perennial herbal plant with vital diabetic ameliorating properties. Findings from previous studies reported diabetic healing efficacy of Molineria latifolia crude extract by upregulating key genes (IRS-1, Glut4 and IGF-1) in insulin-signalling pathways [118]. An investigation using high-fat diet (HFD)-induced diabetic animal models demonstrated that treatment of male rats with polyphenol-rich ethyl acetate fraction (100-200 mg/kg BW) from Molineria latifolia significantly increased the expression of insulin-signalling effectors such as IRS1, IRS2, Akt2 Glut4 and hexokinase 2 (HK2) through phosphorylation of IRS1/Akt pathway in skeletal muscle tissues [105]. This was associated with increased insulin sensitivity and improved glucose uptake, thereby reducing insulin resistance [119].

Mulberry leaf (Folium Mori) phenolic-rich extract is widely known for its diabetic mitigating properties and has been extensively used in Chinese medicines to treat diabetic symptoms such as high blood glucose, hyperlipidaemia and diabetic-induced nephropathy [120]. In treating STZ-induced diabetic rats with $(2 \mathrm{~g} / \mathrm{kg} \mathrm{BW})$ the extract was shown to increase the expression of insulin signalling genes (IRS-1, PI3K, and Glut4) in skeletal tissue, which, as a result, reduced insulin resistance effects, improved glucose tolerance and significantly reduced plasma glucose levels [106]. These findings suggest that Folium mori extract can upregulate insulin sensing genes and ameliorate insulin resistance by activating the IRS-1/PI3K/Glut4 pathway.

\subsection{Polyphenols and Gene Modulations on Gluconeogenesis Pathways}

In hepatocytes, elevated FFA levels lead to ectopic fat deposition (storage of triglycerides in tissue other than adipose tissues), which consequently inhibits IRS2-associated AKT/PI3K cascade activation and Glut2 expression, reducing insulin-stimulated glucose uptake (insulin resistance) [121]. Ectopic fat-induced inhibition of AKT/PI3K decreases the phosphorylation of FOXO1, which, as a result, activates the transcription of glucose-6-phosphatase (G6Pase) and phosphoenolpyruvate carboxykinase (PEPCK), the rate-limiting enzymes for gluconeogenesis [122]. The resulting increased hepatic glucose production leads to hyperglycaemia and the development of T2DM [123,124]. 
Cinnamon extracts (CE) have been reported to improve insulin sensitivity and glucose homeostasis by regulating hepatic enzymes activities, attributed to its phytochemical composition such as cinnamic acid, cinnamaldehyde and proanthocyanidins [125]. Supplementation of rat hepatoma cells (H4IIE) with $(1-25 \mu \mathrm{g} / \mathrm{mL})$ CE was demonstrated to inhibit hepatic glucose production by downregulating the expression of PEPCK and G6pase (Figure 2), concomitantly decreasing blood glucose levels [126]. Such insulin-like and glucose-lowering effects of CE may help to ameliorate T2DM conditions.

Fructus corni (Cornus officinalis) is another polyphenol-rich (loganin and ursolic) plant known for its stimulatory role of liver and glucose uptake diabetic lowering activities [127]. Treatment with $50 \mathrm{mg} / \mathrm{mL}$ of Fructus corni extracts demonstrated insulin-mimetic effects by inhibiting the expression of PEPCK [128] in the liver tissue, whereas, loganin and ursolic compounds failed to exhibit any effect on PEPCK expression. This suggests that these two major components may not be the only putative actives in the extract and that some other compounds may be responsible for the potent synergistic bioactive effects in the gluconeogenesis pathway.

In addition to its potent insulin secretion abilities, EGCG also inhibits glucose production in hepatocytes. Incubation of H4IIE cells with EGCG $(5-25 \mu \mathrm{M})$ was shown to suppress PEPCK and G6Pase genes via PI3K activation in a dose-dependent manner [57], resulting in reduced hepatic glucose output (Figure 2). It was also shown, in the same study, that treatment of H4IIE with EGCG (up to $50 \mu \mathrm{M}$ for 30-240 $\mathrm{min}$ ) promoted tyrosine phosphorylation of insulin signalling proteins such as IR- $\beta$, IRS-1 and IGF-1R through Akt/PI3K activation, owing to its insulin-mimetic properties. On the contrary, later investigations argued that the suppression of glucose production by EGCG does not involve the activation of insulin signalling pathway, as inhibition of PI3K demonstrated no effects on the activities of EGCG [129]. Nevertheless, both studies concurred that EGCG suppression of hepatic gluconeogenesis was dependent on initial production of ROS, a known activator of $\mathrm{Ca} 2+/$ calmodulin-dependent protein kinase kinase (CaMKK) [130] and tyrosine-phosphorylated proteins [131]. The exact mechanisms of how EGCG activates CaMKK via ROS production are, however, still unclear. As such, further investigations are warranted to identify molecular targets for the management of T2DM.

Extracts from germinated-brown rice arguably contain a higher amount of bioactive compounds than brown rice and have thus been known for their diverse diabetic lowering activities including blood glucose-lowering effects, improved total plasma cholesterol and enhanced hepatic function [132]. The diabetic mitigating properties of germinated-brown rice products have been related to the presence of bioactive compounds such as gamma-amino butyric acid, acylated steryl glycoside, oryzanol, and other phenolics [133]. A nutrigenomic investigation reported that exposure of hepatic cells (HEPG2) and diabetic rats (Sprague-Dawley) to $50 \mathrm{ppm}$ and 50-100 ppm of germinated-brown rice extracts, respectively, downregulated hepatic gluconeogenic genes such as Fructose-1,6-bisphosphatase (Fbp1) and Phosphoenolpyruvate carboxykinase 1 (Pck1), more potently than metformin [134]. This, as a result, inhibited hepatic glucose output and reduced blood glucose levels, suggesting that germinated-brown rice extract may provide anti-hyperglycaemic properties by inhibiting hepatic glucose production and, therefore, help to manage T2DM.

Hesperidin and naringin are citrus flavonoids with implicated antioxidant capacity, lipid and glucose-lowering effects [135]. In hyperglycaemic-induced diabetic mice, treatment with hesperidin and naringin $(0.2 \mathrm{~g} / \mathrm{kg} \mathrm{BW})$ for 5 weeks downregulated G6Pase and PEPCK in liver tissue, thereby reducing blood glucose levels [136].

Coupled with its potent $\beta$-cell genes upregulation and insulin secretion ameliorating properties, resveratrol has also been shown to modulate the expression of genes controlling hepatic gluconeogenesis processes in T2DM (Table 4). Animal studies revealed that treatment of diabetic mice (C57BL/KsJ- $d b / d b)$ with resveratrol $(0.02 \%, w / w)$ for 6 weeks significantly decrease the expression of hepatic gluconeogenic genes SREBP-1c, PECK and G6P by activating AMPK and its downstream targets in liver tissues [137]. The resulting inhibition of hepatic glucose output was correlated with reduced blood glucose and plasma FFA levels and improved hepatic function. This suggests resveratrol as a potential agent to help manage T2DM through the activation of AMPK pathway. 
Table 4. Polyphenols and gene modulations on gluconeogenesis pathways.

\begin{tabular}{|c|c|c|c|c|c|}
\hline Polyphenols & Genes Affected & Function & Pathways & $\begin{array}{l}\text { Cells/Tissue } \\
\text { Type }\end{array}$ & Ref. \\
\hline \multicolumn{6}{|c|}{ In vitro models } \\
\hline $\begin{array}{l}\text { Cinnamon extract } \\
(1-25 \mu \mathrm{g} / \mathrm{mL})\end{array}$ & $\downarrow$ PEPCK, $\downarrow$ G6Pase & $\begin{array}{c}\downarrow \text { Hepatic } \\
\text { glucose output }\end{array}$ & PEPCK & Cells-H4IIE & [126] \\
\hline $\begin{array}{l}\text { Fructus Corni } \\
(50 \mathrm{mg} / \mathrm{mL})\end{array}$ & $\downarrow$ PEPCK & $\begin{array}{l}\downarrow \text { Hepatic } \\
\text { Glucose out put }\end{array}$ & Gluconeogenesis & Cells-H4IIE & [128] \\
\hline EGCG $(5-25 \mu \mathrm{M})$ & $\downarrow$ PEPCK, $\downarrow$ G6Pase & $\begin{array}{c}\downarrow \text { Hepatic } \\
\text { glucose out put }\end{array}$ & PI3K & Cells-H4IIE & [57] \\
\hline EGCG $(\leq 1-10 \mu \mathrm{M})$ & $\downarrow$ PEPCK, $\downarrow$ G6Pase & $\begin{array}{c}\downarrow \text { Hepatic } \\
\text { glucose output }\end{array}$ & AMPK/CaMKK & Cells-H4IIE & [130] \\
\hline $\begin{array}{l}\text { Germinated black rice } \\
(50 \mathrm{ppm})\end{array}$ & $\downarrow$ Pck1, $\downarrow$ Fbp 1 & $\begin{array}{c}\downarrow \text { Hepatic } \\
\text { glucose output }\end{array}$ & Gluconeogenesis & Cells-HepG2 & [134] \\
\hline \multicolumn{6}{|c|}{ In vivo models } \\
\hline $\begin{array}{l}\text { Germinated black rice } \\
(50-100 \mathrm{ppm})\end{array}$ & $\downarrow$ Pck1, $\downarrow$ Fbp 1 & $\begin{array}{c}\downarrow \text { Hepatic } \\
\text { glucose output }\end{array}$ & Gluconeogenesis & $\begin{array}{l}\text { Liver- Sprague- } \\
\text { Dawley rats }\end{array}$ & [134] \\
\hline $\begin{array}{c}\text { Hesperidin and } \\
\text { Naringin }(0.2 \mathrm{~g} / \mathrm{kg} \mathrm{BW})\end{array}$ & $\downarrow$ G6Pase, $\downarrow$ PEPCK & $\begin{array}{c}\downarrow \text { Hepatic } \\
\text { glucose output }\end{array}$ & Gluconeogenesis & $\begin{array}{l}\text { Liver-C57BL/ } \\
\text { KsJ- } d b / d b \text { mice }\end{array}$ & [136] \\
\hline $\begin{array}{l}\text { Resveratrol } \\
(0.02 \% w / w)\end{array}$ & $\begin{array}{c}\downarrow \text { PECK, } \downarrow \text { G6P, } \uparrow \text { GK, } \\
\downarrow \text { SREBP-1c }\end{array}$ & $\begin{array}{c}\uparrow \text { Hepatic } \\
\text { glucose uptake }\end{array}$ & PEPCK/AMPK & $\begin{array}{l}\text { Liver-C57BL/ } \\
\text { KsJ- } d b / d b \text { mice }\end{array}$ & [137] \\
\hline $\begin{array}{l}\text { Fermented food paste } \\
\quad(0.1-1.0 \mathrm{~kg} / \mathrm{BW})\end{array}$ & $\begin{array}{c}\uparrow \mathrm{G} 6 \mathrm{PD}, \uparrow \mathrm{GCK}, \uparrow \\
\mathrm{PFK}, \uparrow 6 \mathrm{PGD}\end{array}$ & $\begin{array}{l}\uparrow \text { Glycogen } \\
\text { synthesis, } \uparrow \\
\text { Hepatic insulin } \\
\text { sensitivity, } \downarrow \\
\text { Hepatic } \\
\text { glucose output }\end{array}$ & Glycolysis & $\begin{array}{l}\text { Liver-Balb/c } \\
\text { mice }\end{array}$ & [138] \\
\hline \multicolumn{6}{|c|}{$\begin{array}{l}\text { PEPCK-Phosphoenolpyruvate carboxykinase; G6Pase-Glucose-6-phosphatase; Pck1-Phosphoenolpyruvate } \\
\text { carboxykinase 1; Fbp1-Fructose-1,6-bisphosphatase 1; GK-glucokinase; SREBP-1c—-sterol regulatory } \\
\text { element-binding protein-1c; G6PD-glucose-6-phosphate dehydrogenase; GCK-glucokinase gene; } \\
\text { PFK-Phosphofructokinase; 6PGD-6-Phosphogluconate dehydrogenase deficiency; AMPK-Adenine } \\
\text { monophosphate activated protein kinase; CaMKK-Ca2+/calmodulin-dependent protein kinase kinase; } \\
\uparrow-\text { increased gene expression; } \downarrow-\text { decreased gene expression. }\end{array}$} \\
\hline
\end{tabular}

Fermented food paste (FFP) is a source of polyphenols, including caffeolyquinic acid and sakuranetin, with potential diabetic relieving properties associated with its hyperglycaemic regulatory role and hepatic protective mechanisms [138]. Supplementation of streptozotocin (STZ)-induced diabetic mice with FFP $(0.1$ and $1.0 \mathrm{~g} / \mathrm{kg}$ BW) for 6 weeks upregulated the expression of $G K$, phosphofructokinase (PFK), and 6-phosphogluconate dehydrogenase (6PGD) genes in the liver tissue, responsible for hepatic glycolysis (breaking down of glucose to ATP) [138]. Such modulatory effects were correlated with hepatic insulin sensitivity and glucose uptake, inhibiting hepatic gluconeogenesis. Besides glucose output inhibit, FFP was also shown (by the same study) to increase the expression of glucose transporter genes (Glut1, Glut4, and Glut8) and adiponectin gene, but inhibits pro-inflammatory cytokines (IL-1 $\beta$ and TNF- $\alpha$ ). This may suggest diverse diabetic lowering activities of FFP, indicating a potential for glucohomeostasis management in T2DM.

\subsection{Effects of Polyphenols on Lipid Peroxidation Pathways}

Excessive FFAs has been associated with increased ROS, which through various molecular receptors, attach to cell membranes and initiate progressive lipid oxidation to form lipid peroxide. This mechanism renders the double bonds of polyunsaturated fatty acids unstable leading to cellular injury, thereby disrupting cellular signalling mechanisms controlling glucohomeostasis $[139,140]$. Various polyphenols and phenolic compounds have been shown to possess adipogenic gene modulatory effects attributed to their antihyperlipidaemic properties. 
Consumption of pomegranate (Punica granatum Linn), rich in phenolic compounds such as ellagic acid, flavonoids, anthocyanins and punicalagin [141], has been linked to an increased level of antioxidant enzyme activities, reduced lipid peroxidation and improved glucose homeostasis [142,143]. In vitro study using liver cells (HepG2) and in vivo study using male Zucker diabetic rats demonstrated that pomegranate flower extract upregulated key adipogenic genes $P P A R \alpha$, carnitine palmitoyltransferase-1 (CPT-1) and acyl-CoA oxidase (ACO), while PPAR $\gamma$ remained unchanged in both HepG2 and liver tissue from the diabetic rats [144]. This substantially reduced triglycerides level and lipid accumulation in the liver (ectopic lipid storage), thereby improving hepatic glucose metabolisms.

Punicic acid (PA) from pomegranate was shown to enhance the expression of PRAR $\alpha$ and $\gamma$, and fatty acid-binding protein 4 (FABP4) in muscle cells of $d b / d b$ mice, increasing insulin sensitivity [145]. FABP4 is involved in glucose and lipid metabolism, and its upregulation has been associated with the development of insulin resistance and T2DM [146]. As such, its upregulation reported here may need further investigations. Supplementation of 3T3-L1 with PA $(30 \mu \mathrm{M})$ increased the expression of PPAR $\gamma$, Glut4 (Figure 2) and reduced ROS [147]. However, in recent studies using an adipocyte cell line (3T3-L1), PA and its main polyphenols (ellagic acid, punicalagin and the gastrointestinal metabolite urolithin A) downregulated PPAR- $\gamma$, Glut4 and FABP4 [148,149]. Although variations in study design and cell models may contribute to the conflicting results, pomegranate extracts may upregulate the expression of adipogenic genes to enhance free fatty acid uptake into the targeted tissues (muscles, liver and adipose tissues) while inhibiting their expression in adipocyte saturated tissues (intestines). Besides genetic modulation, pomegranate extracts have also been shown to inhibit the activities of key enzymes linked to T2DM (DPP-4, $\alpha$-glucosidase and lipase) and reduced lipid accumulation in 3T3-L1 adipocyte-like cells [148].

\subsection{Effect of Polyphenols on Inflammatory Pathways}

Under chronic glucolipotoxicity, overproduction of ROS leads to protein oxidation which consequently generates pro-inflammatory signals (peroxiredoxin 2). This triggers an inflammatory response recruiting M1 macrophages activated via toll-like receptor-4 (TLR-4) to produce pro-inflammatory markers such as TNF- $\alpha$, interleukin $1 \beta$ (IL-1 $\beta$ ), IL-6 and MCP1 [150]. IL-6 and TNF activate the Janus kinase/signal transducer and activator of transcription (JAK/SAT) and mitogen-activated protein kinase (MAPK), respectively, inducing cellular damage and insulin resistance. Lines of evidence have reported that polyphenols can downregulate key inflammatory markers such as protein kinase-c, cyclooxygenase-2 (COX-2) and inhibit major mediating pathways such as NF- $\mathrm{kB}$, inducible nitric oxide synthase (iNOS) and MAPK [151]. Phenolic compounds have also been shown to modulate inflammatory signalling processes by altering enzymatic activities such as tyrosine and serine-threonine protein kinase.

Punicic acid (PA) from pomegranate has also been shown to possess anti-inflammatory activities by suppressing the expression of pro-inflammatory molecules in addition to its enhanced lipid metabolic activities. In obese diabetic mice, treatment with 5 and $10 \mu \mathrm{M}$ PA suppressed NF- $k B$ and TNF- $\alpha$ in both adipose and liver tissue, in a dose-dependent manner [145]. Coupled with its insulin signalling ameliorating effects, as mentioned above, ASP has also been proven to downregulate inflammatory genes suppressor of cytokine signalling 3 (Socs3), tumour necrosis factor receptor superfamily (Tnfsf), CD44, JAK/STAT and MAPK) and pro-apoptotic genes (Mapk3, optic atrophy 1 (Opa1) and Chuck) by neutralising intracellular ROS and reducing DNA nick formation [104].

Besides their effective insulin signalling proficiency, the diabetic reducing behaviours of anthocyanins have also been attributed to their anti-inflammatory and anti-oxidative functions. Treatment of diabetic cells (HK-2) with anthocyanins derivatives C3G and cyanidin chloride (Cy) at $50 \mu \mathrm{M}$ markedly increased the expression of PPRAR $\alpha$ and LXR $\alpha$ genes [152]. This caused the downregulation of hyperglycaemic-induced pro-inflammatory cytokines namely intracellular adhesion molecule-1 (ICAM1), transforming growth factor- $\beta 1$ (TGF $\beta 1$ ) and monocyte chemoattractant protein-1 (MCP-1) by inhibiting the NF- $\mathrm{kB}$ pathway (Figure 2). Another study (on diabetic primary HK-2 cells) 
supporting these findings demonstrated that supplementation with anthocyanins $(10 \mu \mathrm{M})$ suppressed the expression of apoptosis-related genes (thioredoxin interacting protein (TXNIP), Bcl-2, caspase-3 and ROS) by inhibiting p38MAPK and ERK1/2 phosphorylation [153]. The resulting decrease in cellular glucose level has been associated with improved diabetic nephropathy, a primary complication of T2DM [154].

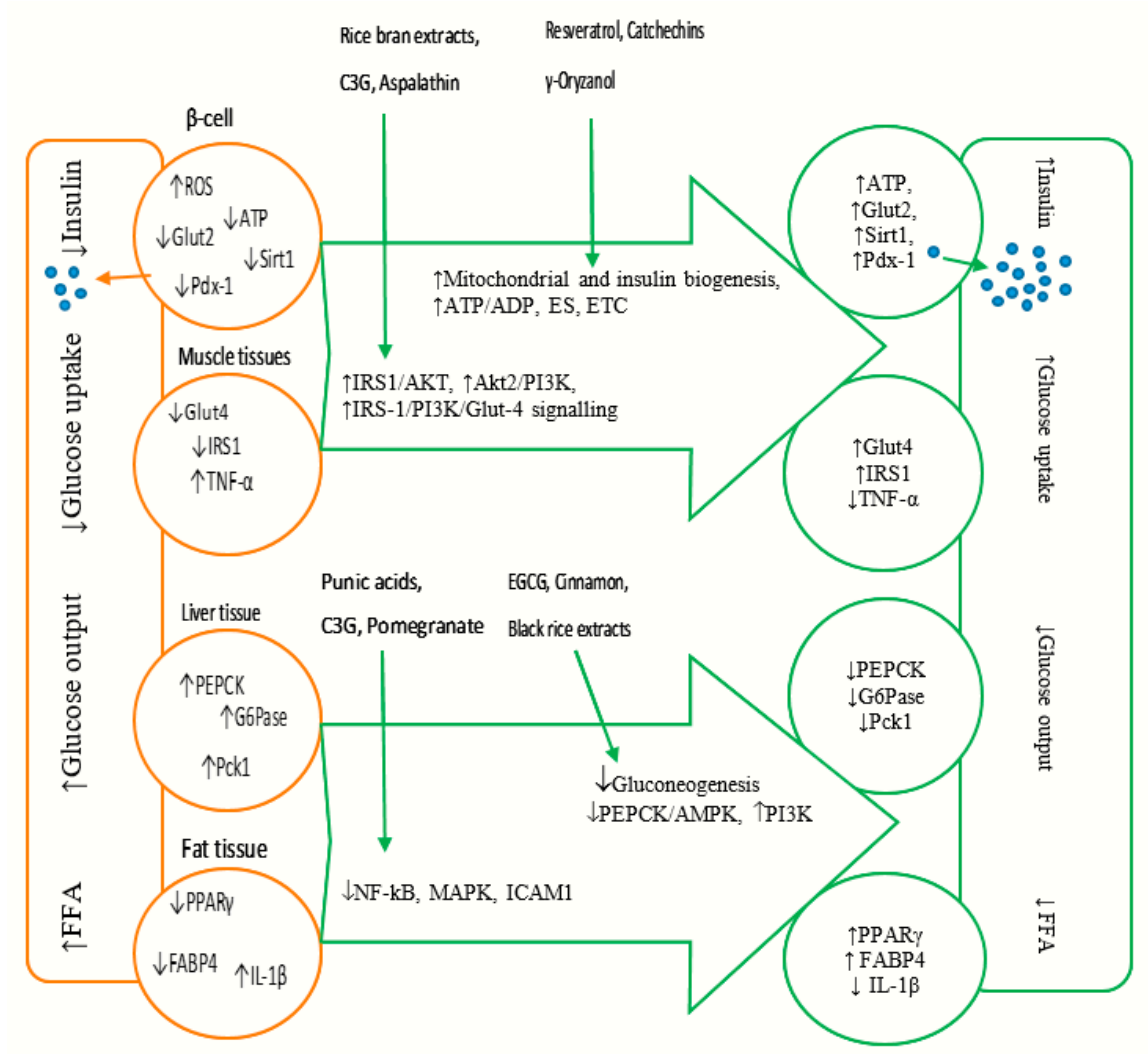

Figure 2. Schematic summary of how various plant-derived phenolic compounds target signalling pathways on various cell types and tissues in type 2 diabetes mellitus. ROS-reactive oxygen species; ATP-Adenosine triphosphate; Glut2-glucose transporter 2; Glut4-glucose transporter 4; Sirt1-Sirtuin 1; Pdx-1—pancreas and duodenal homeobox 1; IRS1—insulin receptor substrate 1; TNF- $\alpha$-tumour necrosis factor alpha; ADP_Adenosine diphosphate; ES-endoplasmic reticulum stress; AKT-Protein kinase B; PI3K-Phosphatidylinositol 3-kinase; PEPCK-Phosphoenolpyruvate carboxykinase; G6Pase-Glucose-6-phosphatase; PcK1-Phosphoenolpyruvate carboxykinase 1; PPAR $\gamma$-peroxisome proliferator-activated receptor; FABP4-fatty acid binding protein 4; IL-1 $\beta$-Interleukin 1 $\beta$; NF-kB-Nuclear factor kappa light chain enhancer of activated B cells; MAPK - mitogen activated protein kinase; ICAM1—intracellular adhesion molecules-1; C3G_Cyanidin 3-glucoside; EGCG-Epigallocatechin gallate; black arrows: $\uparrow$ —increased gene expression and $\downarrow$-decreased gene expression); orange arrow-decreased insulin secretion under hyperglycaemic condition; short green arrow-increased insulin secretion after polyphenols treatment; long green arrows-different polyphenol extracts and phenolic compounds targeting various pathways.

ROS-induced inflammation is also linked with epigenetic modifications, leading to the generation of cytokines. The flavonoid fisetin, commonly found in fruits and vegetables, has been known to offer diabetic healing effects by regulating histone deacetylases (HDACs) activities. In hyperglycaemic human monocytes (THP-1), treatment with fisetin $(3-10 \mu \mathrm{M})$ was reported to activate HDACs and downregulated histone acetylates (HAT) activities, thereby inhibiting NF- $\mathrm{KB}$ pathways and suppressing cytokine release [155]. In another study using THP-1 cells, (-)-Epicatechin (EC), a major compound in flavanols, was shown to mitigate hyperglycaemic-induced histone acetylation by initiating chromatin remodelling which prevents p65-NF- $\mathrm{kB}$ binding to the TNF- $\alpha$ promoter thereby inhibiting 
its expression [156]. This resulted in decreased cytokine release and improved glucose uptake. Adding to its spicy nature, curcumin (found in turmeric) has been suggested to exert potent anti-inflammatory effects [157], validating the reasoning for seasoning. In THP-1 cells (exposed to $25 \mathrm{mM}$ glucose), supplementation with curcumin $(1.5-12.5 \mu \mathrm{M})$ significantly downregulated HAT activity, P300 level and $C B P / p 300$ gene expression by suppressing NF- $\kappa B$ binding to TNF- $\alpha$ [156].

\section{Conclusions}

T2DM is a multifaceted disease with various contributing factors including over-nutrition and genetic dysregulation, leading to insulin deficiency (also referred to as $\beta$-cell dysfunction) and insulin resistance. Over-nutrition contributes to hyperglycaemia and hyperlipidaemia generating oxidative stress, which, as a result, induces cellular metabolic dysregulations. This affects gene expression in major pathways controlling glucohomeostasis. Polyphenolic compounds have antioxidant properties and can modulate the expression of genes along these pathways to mitigate the diabetic effects (Figure 2). The exact mechanisms of action of polyphenols are not well understood, but polyphenol structural elements play a significant role in relation to their interactions with other proteins, absorption, transportation and bioavailability. Further studies are warranted to identify polyphenols with specific functions and thus may offer a therapeutic remedy for the management of T2DM.

Author Contributions: G.G.K. conducted the review of literature and drafted the manuscript; N.F., R.H., D.W.; C.B., and A.B.S. were involved in the design and critical review of this manuscript. All authors have read and agreed to the published version of the manuscript.

Funding: This research received no external funding.

Acknowledgments: This work was supported by the Graham Centre for Agricultural Innovation, Australia. We also acknowledge the financial support provided by the Faculty of Science, Charles Sturt University, to cover the publication costs.

Conflicts of Interest: The authors declare no conflict of interest.

$\begin{array}{ll}\text { Abbreviations } \\ \text { 6PGD } & \text { 6-phosphogluconate dehydrogenase } \\ \text { ACC2 } & \text { Acetyl CoA carboxylase 2 } \\ \text { ACO } & \text { acyl-CoA oxidase } \\ \text { ADP } & \text { Adenosine diphosphate } \\ \text { Akt } & \text { Protein kinase B } \\ \text { AMPK } & \text { Adenine monophosphate activated protein kinase } \\ \text { ATP } & \text { Adenosine triphosphate } \\ \text { BIP } & \text { Binding immunoglobulin protein } \\ \text { C3G } & \text { Cyanidin 3-glucoside } \\ \text { CAD } & \text { Caspase-activated DNase } \\ \text { CAMFs } & \text { Methanolic fraction of C. anthelminticum seeds } \\ \text { CaMKK } & \text { Ca2+/calmodulin-dependent protein kinase kinase } \\ \text { cAMP } & \text { Cyclic adenosine } 3^{\prime}, 5^{\prime} \text {-monophosphate } \\ \text { CAT } & \text { Catalase } \\ \text { Cdkn1a } & \text { Cyclin-dependent kinase inhibitor 1A } \\ \text { cDNA } & \text { Complementary deoxyribonucleic acid } \\ \text { CHOP } & \text { C/EBP-homologous protein } \\ \text { COX-2 } & \text { cyclooxygenase-2 } \\ \text { CPT-1 } & \text { carnitine palmitoyltransferase-1 } \\ \text { Dnajb9 } & \text { DnaJ homolog subfamily B member 9 } \\ \text { DPP-4 } & \text { Dipeptidyl-peptidase-4 } \\ \text { EGCG } & \text { Epigallocatechin gallate } \\ \text { eIF2 } \alpha & \text { Inositol-requiring kinase 2 } \alpha \\ \text { ENOS } & \text { Endothelial nitric oxide synthase } \\ \text { ER } & \text { Endoplasmic reticulum }\end{array}$




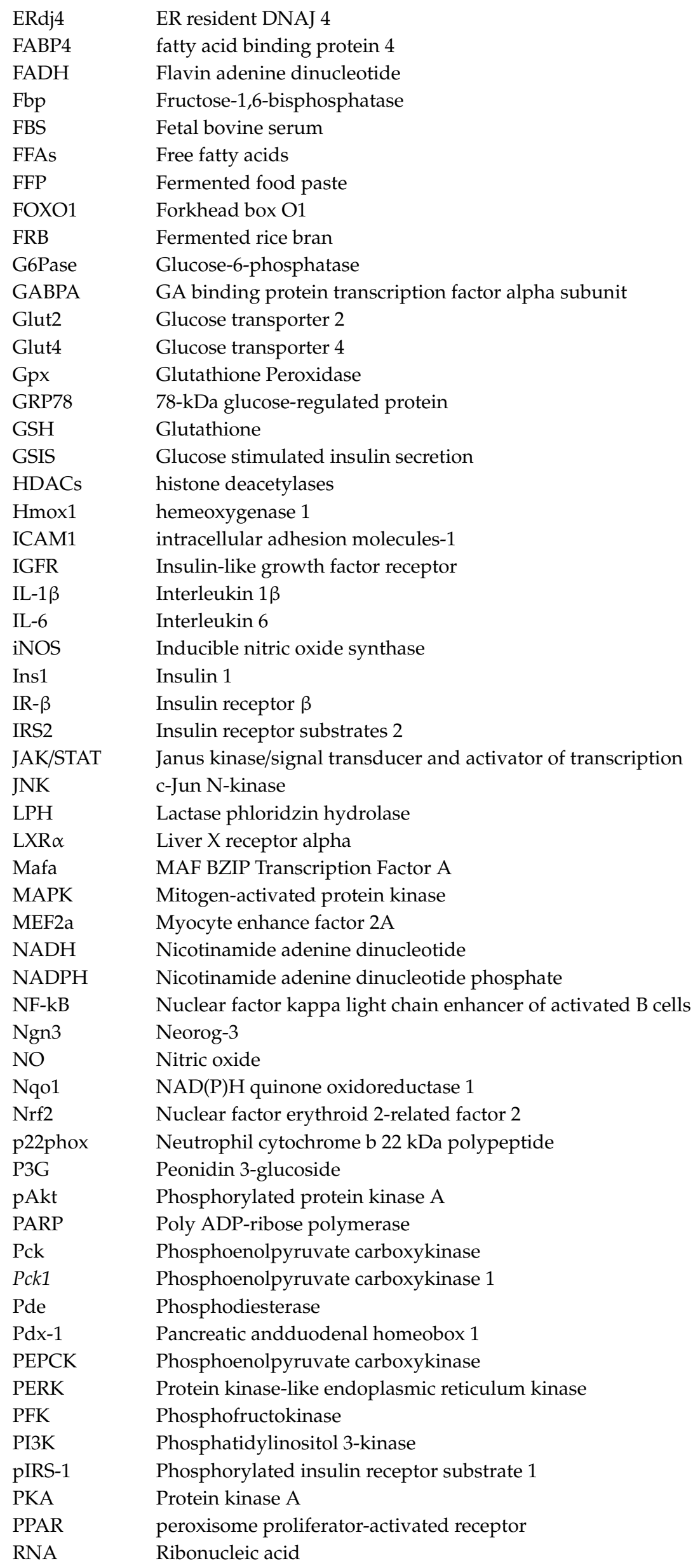




$\begin{array}{ll}\text { RNS } & \text { Reactive nitrogen species } \\ \text { ROS } & \text { Reactive oxygen species } \\ \text { RTK } & \text { Receptor tyrosine kinases } \\ \text { Sirt1 } & \text { Sirtuin } 1 \\ \text { Socs3 } & \text { Suppressor of cytokine signalling } 3 \\ \text { SOD2 } & \text { Superoxide dismutase } 2 \\ \text { SREBP-1c } & \text { sterol regulatory element-binding protein-1c } \\ \text { T2DM } & \text { Type 2 diabetes mellitus } \\ \text { TCA } & \text { Tricarboxylic acid } \\ \text { Tfam } & \text { Mitochondrial transcription factor A } \\ \text { TGF } \beta 1 & \text { Transforming growth factor- } \beta 1 \\ \text { TNF- } \alpha & \text { Tumour necrosis factor alpha } \\ \text { Tnfsf } & \text { Tumour necrosis factor receptor superfamily } \\ \text { TXNIP } & \text { Thioredoxin interacting protein } \\ \text { UPR } & \text { Unfolded protein response } \\ \text { Xbp1s } & \text { X box binding protein } 1\end{array}$

\section{References}

1. NCD Risk Factor Collaboration. Worldwide trends in diabetes since 1980: A pooled analysis of 751 population-based studies with 4.4 million participants. Lancet 2016, 387, 1513-1530. [CrossRef]

2. Cho, N.H.; Shaw, J.E.; Karuranga, S.; Huang, Y.; da Rocha Fernandes, J.D.; Ohlrogge, A.W.; Malanda, B. IDF Diabetes Atlas: Global estimates of diabetes prevalence for 2017 and projections for 2045. Diabetes Res. Clin. Pract. 2018, 138, 271-281. [CrossRef]

3. Holman, N.; Young, B.; Gadsby, R. Current prevalence of Type 1 and Type 2 diabetes in adults and children in the UK. Diabet. Med. 2015, 32, 1119-1120. [CrossRef] [PubMed]

4. Valko, M.; Leibfritz, D.; Moncol, J.; Cronin, M.T.; Mazur, M.; Telser, J. Free radicals and antioxidants in normal physiological functions and human disease. Int. J. Biochem. Cell Biol. 2007, 39, 44-84. [CrossRef] [PubMed]

5. Migdal, C.; Serres, M. Reactive oxygen species and oxidative stress. Med. Sci. 2011, 27, 405-412. [CrossRef]

6. DeFronzo, R.A.; Tripathy, D. Skeletal muscle insulin resistance is the primary defect in type 2 diabetes. Diabetes Care 2009, 32, S157-S163. [CrossRef]

7. Gallagher, E.J.; LeRoith, D.; Karnieli, E. Insulin Resistance in Obesity as the Underlying Cause for the Metabolic Syndrome. Mt. Sinai J. Med. J. Transl. Pers. Med. 2010, 77, 511-523. [CrossRef]

8. Aryaeian, N.; Sedehi, S.K.; Arablou, T. Polyphenols and their effects on diabetes management: A review. Med. J. Islam. Repub. Iran 2017, 31, 134. [CrossRef]

9. Vetterli, L.; Brun, T.; Giovannoni, L.; Bosco, D.; Maechler, P. Resveratrol potentiates glucose-stimulated insulin secretion in INS-1E beta-cells and human islets through a SIRT1-dependent mechanism. J. Biol. Chem. 2011, 286, 6049-6060. [CrossRef]

10. Scazzocchio, B.; Vari, R.; Filesi, C.; D’Archivio, M.; Santangelo, C.; Giovannini, C.; Iacovelli, A.; Silecchia, G.; Li Volti, G.; Galvano, F.; et al. Cyanidin-3-O- $\beta$-glucoside and protocatechuic acid exert insulin-like effects by upregulating PPARgamma activity in human omental adipocytes. Diabetes 2011, 60, 2234-2244. [CrossRef]

11. Lin, C.-L.; Lin, J.-K. Epigallocatechin gallate (EGCG) attenuates high glucose-induced insulin signaling blockade in human hepG2 hepatoma cells. Mol. Nutr. Food Res. 2008, 52, 930-939. [CrossRef] [PubMed]

12. Lin, G.; Liu, X.; Yan, X.; Liu, D.; Yang, C.; Liu, B.; Huang, Y.; Zhao, C. Role of Green Macroalgae Enteromorpha Prolifera Polyphenols in the Modulation of Gene Expression and Intestinal Microflora Profiles in Type 2 Diabetic Mice. Int. J. Mol. Sci. 2018, 20, 25. [CrossRef] [PubMed]

13. Schulze, M.B.; Hu, F.B. Primary prevention of diabetes: What can be done and how much can be prevented? Annu. Rev. Public Health 2005, 26, 445-467. [CrossRef] [PubMed]

14. Erukainure, O.L.; Ijomone, O.M.; Oyebode, O.A.; Chukwuma, C.I.; Aschner, M.; Islam, M.S. Hyperglycemia-induced oxidative brain injury: Therapeutic effects of Cola nitida infusion against redox imbalance, cerebellar neuronal insults, and upregulated Nrf2 expression in type 2 diabetic rats. Food Chem. Toxicol. 2019, 127, 206-217. [CrossRef] 
15. Jiang, J.; Briedé, J.J.; Jennen, D.G.J.; Van Summeren, A.; Saritas-Brauers, K.; Schaart, G.; Kleinjans, J.C.S.; de Kok, T.M.C.M. Increased mitochondrial ROS formation by acetaminophen in human hepatic cells is associated with gene expression changes suggesting disruption of the mitochondrial electron transport chain. Toxicol. Lett. 2015, 234, 139-150. [CrossRef]

16. Wang, J.; Wang, H. Oxidative Stress in Pancreatic Beta Cell Regeneration. Oxidative Med. Cell. Longev. 2017, 2017, 1930261. [CrossRef]

17. Tangvarasittichai, S. Oxidative stress, insulin resistance, dyslipidemia and type 2 diabetes mellitus. World J. Diabetes 2015, 6, 456-480. [CrossRef]

18. Houstis, N.; Rosen, E.D.; Lander, E.S. Reactive oxygen species have a causal role in multiple forms of insulin resistance. Nature 2006, 440, 944-948. [CrossRef]

19. Boden, G.; Chen, X.; Stein, T.P. Gluconeogenesis in moderately and severely hyperglycemic patients with type 2 diabetes mellitus. Am. J. Physiol. Endocrinol. Metab. 2001, 280, E23-E30. [CrossRef]

20. Defronzo, R.A. From the triumvirate to the ominous octet: A new paradigm for the treatment of type 2 diabetes mellitus. Diabetes 2009, 58, 773-795. [CrossRef]

21. Han, X.; Shen, T.; Lou, H. Dietary Polyphenols and Their Biological Significance. Int. J. Mol. Sci. 2007, 8, 950-988. [CrossRef]

22. Manach, C.; Scalbert, A.; Morand, C.; Rémésy, C.; Jiménez, L. Polyphenols: Food sources and bioavailability. Am. J. Clin. Nutr. 2004, 79, 727-747. [CrossRef] [PubMed]

23. Abbas, M.; Saeed, F.; Anjum, F.M.; Afzaal, M.; Tufail, T.; Bashir, M.S.; Ishtiaq, A.; Hussain, S.; Suleria, H.A.R. Natural polyphenols: An overview. Int. J. Food Prop. 2017, 20, 1689-1699. [CrossRef]

24. Santhakumar, A.B.; Bulmer, A.C.; Singh, I. A review of the mechanisms and effectiveness of dietary polyphenols in reducing oxidative stress and thrombotic risk. J. Hum. Nutr. Diet. 2014, 27, 1-21. [CrossRef] [PubMed]

25. D'Archivio, M.; Filesi, C.; Varì, R.; Scazzocchio, B.; Masella, R. Bioavailability of the polyphenols: Status and controversies. Int. J. Mol. Sci. 2010, 11, 1321-1342. [CrossRef]

26. Ludwig, I.A.; Mena, P.; Calani, L.; Borges, G.; Pereira-Caro, G.; Bresciani, L.; Del Rio, D.; Lean, M.E.; Crozier, A. New insights into the bioavailability of red raspberry anthocyanins and ellagitannins. Free Radical Biol. Med. 2015, 89, 758-769. [CrossRef]

27. Del Rio, D.; Rodriguez-Mateos, A.; Spencer, J.P.; Tognolini, M.; Borges, G.; Crozier, A. Dietary (poly) phenolics in human health: Structures, bioavailability, and evidence of protective effects against chronic diseases. Antioxid. Redox Signal. 2013, 18, 1818-1892. [CrossRef]

28. Frydman, A.; Liberman, R.; Huhman, D.V.; Carmeli-Weissberg, M.; Sapir-Mir, M.; Ophir, R.W.; Sumner, L.; Eyal, Y. The molecular and enzymatic basis of bitter/non-bitter flavor of citrus fruit: Evolution of branch-forming rhamnosyltransferases under domestication. Plant J. 2013, 73, 166-178. [CrossRef]

29. Teng, H.; Chen, L. Polyphenols and bioavailability: An update. Crit. Rev. Food Sci. Nutr. 2018, 59, $2040-2051$. [CrossRef]

30. Smith, C.; Lombard, K.A.; Peffley, E.B.; Liu, W. Genetic analysis of quercetin in onion (Allium cepa L.) 'Lady Raider'. Texas J. Agri. Nat. Resour. 2016, 16, 24-28.

31. Aron, P.M.; Kennedy, J.A. Flavan-3-ols: Nature, occurrence and biological activity. Mol. Nutr. Food Res. 2008, 52, 79-104. [CrossRef] [PubMed]

32. Szeja, W.; Grynkiewicz, G.; Rusin, A. Isoflavones, their glycosides and glycoconjugates. Synthesis and biological activity. Curr. Org. Chem. 2017, 21, 218-235. [CrossRef] [PubMed]

33. Crozier, A.; Borges, G.; Ryan, D. Phenolic and polyphenolic constituents and the beneficial effects of moderate red wine consumption: The glass that cheers. Biochemist 2010, 32, 4-9. [CrossRef]

34. Scalbert, A.; Williamson, G. Dietary Intake and Bioavailability of Polyphenols. J. Nutr. 2000, 130, 2073S-2085S. [CrossRef] [PubMed]

35. Chen, L.; Cao, H.; Xiao, J. Polyphenols: Absorption, Bioavailability, and Metabolomics; Woodhead Publishing: Cambridge, UK, 2018; pp. 45-67. [CrossRef]

36. Guo, Y.; Bruno, R.S. Endogenous and exogenous mediators of quercetin bioavailability. J. Nutr. Biochem. 2015, 26, 201-210. [CrossRef]

37. Danielsen, E.T.; Danielsen, E.M. Glycol chitosan: A stabilizer of lipid rafts in the intestinal brush border. Biochim. Biophys. Acta Biomembr. 2017, 1859, 360-367. [CrossRef] 
38. Bowey, E.; Adlercreutz, H.; Rowland, I. Metabolism of isoflavones and lignans by the gut microflora: A study in germ-free and human flora associated rats. Food Chem. Toxicol. 2003, 41, 631-636. [CrossRef]

39. Graefe, E.U.; Wittig, J.; Mueller, S.; Riethling, A.-K.; Uehleke, B.; Drewelow, B.; Pforte, H.; Jacobasch, G.; Derendorf, H.; Veit, M. Pharmacokinetics and Bioavailability of Quercetin Glycosides in Humans. J. Clin. Pharmacol. 2001, 41, 492-499. [CrossRef]

40. Lee, M.J.; Wang, Z.Y.; Li, H.; Chen, L.; Sun, Y.; Gobbo, S.; Balentine, D.A.; Yang, C.S. Analysis of plasma and urinary tea polyphenols in human subjects. Cancer Epidemiol. Biomark. 1995, 4, 393-399.

41. Wang, J.F.; Schramm, D.D.; Holt, R.R.; Ensunsa, J.L.; Fraga, C.G.; Schmitz, H.H.; Keen, C.L. A dose-response effect from chocolate consumption on plasma epicatechin and oxidative damage. J. Nutr. 2000, 130, 2115S-2119S. [CrossRef]

42. Donovan, J.L.; Bell, J.R.; Kasim-Karakas, S.; German, J.B.; Walzem, R.L.; Hansen, R.J.; Waterhouse, A.L. Catechin is present as metabolites in human plasma after consumption of red wine. J. Nutr. 1999, 129, 1662-1668. [CrossRef] [PubMed]

43. Manach, C.; Morand, C.; Gil-Izquierdo, A.; Bouteloup-Demange, C.; Remesy, C. Bioavailability in humans of the flavanones hesperidin and narirutin after the ingestion of two doses of orange juice. Eur. J. Clin. Nutr. 2003, 57, 235-242. [CrossRef] [PubMed]

44. Erlund, I.; Meririnne, E.; Alfthan, G.; Aro, A. Plasma kinetics and urinary excretion of the flavanones naringenin and hesperetin in humans after ingestion of orange juice and grapefruit juice. J. Nutr. 2001, 131, 235-241. [CrossRef] [PubMed]

45. Cao, G.; Muccitelli, H.U.; Sanchez-Moreno, C.; Prior, R.L. Anthocyanins are absorbed in glycated forms in elderly women: A pharmacokinetic study. Am. J. Clin. Nutr. 2001, 73, 920-926. [CrossRef]

46. Nesbitt, P.D.; Lam, Y.; Thompson, L.U. Human metabolism of mammalian lignan precursors in raw and processed flaxseed. Am. J. Clin. Nutr. 1999, 69, 549-555. [CrossRef]

47. Watanabe, S.; Yamaguchi, M.; Sobue, T.; Takahashi, T.; Miura, T.; Arai, Y.; Mazur, W.; Wahala, K.; Adlercreutz, H. Pharmacokinetics of soybean isoflavones in plasma, urine and feces of men after ingestion of $60 \mathrm{~g}$ baked soybean powder (kinako). J. Nutr. 1998, 128, 1710-1715. [CrossRef]

48. Holt, R.R.; Lazarus, S.A.; Sullards, M.C.; Zhu, Q.Y.; Schramm, D.D.; Hammerstone, J.F.; Fraga, C.G.; Schmitz, H.H.; Keen, C.L. Procyanidin dimer B2 [epicatechin-(4 $\beta-8)$-epicatechin] in human plasma after the consumption of a flavanol-rich cocoa. Am. J. Clin. Nutr. 2002, 76, 798-804. [CrossRef]

49. Serreli, G.; Deiana, M. In vivo formed metabolites of polyphenols and their biological efficacy. Food Funct. 2019, 10, 6999-7021. [CrossRef]

50. Lee, M.J.; Maliakal, P.; Chen, L.; Meng, X.; Bondoc, F.Y.; Prabhu, S.; Lambert, G.; Mohr, S.; Yang, C.S. Pharmacokinetics of tea catechins after ingestion of green tea and (-)-epigallocatechin-3-gallate by humans: Formation of different metabolites and individual variability. Cancer Epidemiol. Biomark. 2002, 11, 1025-1032.

51. Rice-Evans, C.; Miller, N.; Paganga, G. Antioxidant properties of phenolic compounds. Trends Plant Sci. 1997, 2, 152-159. [CrossRef]

52. Vauzour, D.; Rodriguez-Mateos, A.; Corona, G.; Oruna-Concha, M.J.; Spencer, J.P.E. Polyphenols and Human Health: Prevention of Disease and Mechanisms of Action. Nutrients 2010, 2, 1106-1131. [CrossRef] [PubMed]

53. Erlejman, A.G.; Fraga, C.G.; Oteiza, P.I. Procyanidins protect Caco-2 cells from bile acid-and oxidant-induced damage. Free Radic. Biol. Med. 2006, 41, 1247-1256. [CrossRef] [PubMed]

54. Verstraeten, S.V.; Keen, C.L.; Schmitz, H.H.; Fraga, C.G.; Oteiza, P.I. Flavan-3-ols and procyanidins protect liposomes against lipid oxidation and disruption of the bilayer structure. Free Radic. Biol. Med. 2003, 34, 84-92. [CrossRef]

55. Shimizu, M.; Deguchi, A.; Hara, Y.; Moriwaki, H.; Weinstein, I.B. EGCG inhibits activation of the insulin-like growth factor-1 receptor in human colon cancer cells. Biochem. Biophys. Res. Commun. 2005, 334, 947-953. [CrossRef] [PubMed]

56. Kim, H.S.; Quon, M.J.; Kim, J.A. New insights into the mechanisms of polyphenols beyond antioxidant properties; lessons from the green tea polyphenol, epigallocatechin 3-gallate. Redox Biol. 2014, 2, 187-195. [CrossRef]

57. Waltner-Law, M.E.; Wang, X.L.; Law, B.K.; Hall, R.K.; Nawano, M.; Granner, D.K. Epigallocatechin gallate, a constituent of green tea, represses hepatic glucose production. J. Biol. Chem. 2002, 277, 34933-34940. [CrossRef] 
58. Fraga, C.G.; Galleano, M.; Verstraeten, S.V.; Oteiza, P.I. Basic biochemical mechanisms behind the health benefits of polyphenols. Mol. Asp. Med. 2010, 31, 435-445. [CrossRef]

59. Hong, J.; Lu, H.; Meng, X.; Ryu, J.H.; Hara, Y.; Yang, C.S. Stability, cellular uptake, biotransformation, and efflux of tea polyphenol (-)-epigallocatechin-3-gallate in HT-29 human colon adenocarcinoma cells. Cancer Res. 2002, 62, 7241-7246.

60. Colin, D.; Limagne, E.; Jeanningros, S.; Jacquel, A.; Lizard, G.; Athias, A.; Gambert, P.; Hichami, A.; Latruffe, N.; Solary, E.; et al. Endocytosis of Resveratrol via Lipid Rafts and Activation of Downstream Signaling Pathways in Cancer Cells. Cancer Prev. Res. 2011, 4, 1095-1106. [CrossRef]

61. Sun, H.; Mu, B.; Song, Z.; Ma, Z.; Mu, T. The In Vitro Antioxidant Activity and Inhibition of Intracellular Reactive Oxygen Species of Sweet Potato Leaf Polyphenols. Oxid. Med. Cell. Longev. 2018, 2018, 9017828. [CrossRef]

62. Perron, N.R.; Brumaghim, J.L. A review of the antioxidant mechanisms of polyphenol compounds related to iron binding. Cell Biochem. Biophys. 2009, 53, 75-100. [CrossRef] [PubMed]

63. Abdilla, N.; Tormo, M.; Fabia, M.; Chaves, F.; Saez, G.; Redon, J. Impact of the components of metabolic syndrome on oxidative stress and enzymatic antioxidant activity in essential hypertension. J. Hum. Hypertens. 2007, 21, 68. [CrossRef] [PubMed]

64. Brun, T.; Maechler, P. Beta-cell mitochondrial carriers and the diabetogenic stress response. Biochim. Biophys. Acta Mol. Cell Res. 2016, 1863, 2540-2549. [CrossRef] [PubMed]

65. Saraste, M. Oxidative Phosphorylation at the fin de siècle. Science 1999, 283, 1488. [CrossRef] [PubMed]

66. Maechler, P.; Carobbio, S.; Rubi, B. In beta-cells, mitochondria integrate and generate metabolic signals controlling insulin secretion. Int. J. Biochem. Cell Biol. 2006, 38, 696-709. [CrossRef] [PubMed]

67. Fakhruddin, S.; Alanazi, W.; Jackson, K.E. Diabetes-Induced Reactive Oxygen Species: Mechanism of Their Generation and Role in Renal Injury. J. Diabetes Res. 2017, 2017, 8379327. [CrossRef]

68. Yang, S.N.; Berggren, P.O. Beta-cell CaV channel regulation in physiology and pathophysiology. Am. J. Physiol. Endocrinol. Metab. 2005, 288, E16-E28. [CrossRef]

69. Brownlee, M. The pathobiology of diabetic complications: A unifying mechanism. Diabetes 2005, 54, 1615-1625. [CrossRef]

70. Johnson, R.; Dludla, P.; Joubert, E.; February, F.; Mazibuko, S.; Ghoor, S.; Muller, C.; Louw, J. Aspalathin, a dihydrochalcone $\mathrm{C}$-glucoside, protects $\mathrm{H} 9 \mathrm{c} 2$ cardiomyocytes against high glucose induced shifts in substrate preference and apoptosis. Mol. Nutr. Food Res. 2016, 60, 922-934. [CrossRef]

71. Ortega, Á.; Berná, G.; Rojas, A.; Martín, F.; Soria, B. Gene-Diet Interactions in Type 2 Diabetes: The Chicken and Egg Debate. Int. J. Mol. Sci. 2017, 18, 1188. [CrossRef]

72. Rouse, M.; Younes, A.; Egan, J.M. Resveratrol and curcumin enhance pancreatic beta-cell function by inhibiting phosphodiesterase activity. J. Endocrinol. 2014, 223, 107-117. [CrossRef] [PubMed]

73. Bo, S.; Ponzo, V.; Ciccone, G.; Evangelista, A.; Saba, F.; Goitre, I.; Procopio, M.; Pagano, G.F.; Cassader, M.; Gambino, R. Six months of resveratrol supplementation has no measurable effect in type 2 diabetic patients. A randomized, double blind, placebo-controlled trial. Pharmacol. Res. 2016, 111, 896-905. [CrossRef] [PubMed]

74. Bhatt, J.K.; Thomas, S.; Nanjan, M.J. Resveratrol supplementation improves glycemic control in type 2 diabetes mellitus. Nutr. Res. 2012, 32, 537-541. [CrossRef] [PubMed]

75. Fernández-Millán, E.; Cordero-Herrera, I.; Ramos, S.; Escrivá, F.; Alvarez, C.; Goya, L.; Martín, M.A. Cocoa-rich diet attenuates beta cell mass loss and function in young Zucker diabetic fatty rats by preventing oxidative stress and beta cell apoptosis. Mol. Nutr. Food Res. 2015, 59, 820-824. [CrossRef] [PubMed]

76. Rowley, T.J.; Bitner, B.F.; Ray, J.D.; Lathen, D.R.; Smithson, A.T.; Dallon, B.W.; Plowman, C.J.; Bikman, B.T.; Hansen, J.M.; Dorenkott, M.R.; et al. Monomeric cocoa catechins enhance $\beta$-cell function by increasing mitochondrial respiration. J. Nuatr. Biochem. 2017, 49, 30-41. [CrossRef] [PubMed]

77. Lee, H.; Im, S.W.; Jung, C.H.; Jang, Y.J.; Ha, T.Y.; Ahn, J. Tyrosol, an olive oil polyphenol, inhibits ER stress-induced apoptosis in pancreatic $\beta$-cell through JNK signaling. Biochem. Biophys. Res. Commun. 2016, 469, 748-752. [CrossRef] [PubMed]

78. Belhadj, S.; Hentati, O.; Hamdaoui, G.; Fakhreddine, K.; Maillard, E.; Dal, S.; Sigrist, S. Beneficial Effect of Jojoba Seed Extracts on Hyperglycemia-Induced Oxidative Stress in RINm5f Beta Cells. Nutrients 2018, 10, 384. [CrossRef] 
79. Kozuka, C.; Sunagawa, S.; Ueda, R.; Higa, M.; Tanaka, H.; Shimizu-Okabe, C.; Ishiuchi, S.; Takayama, C.; Matsushita, M.; Tsutsui, M.; et al. gamma-Oryzanol protects pancreatic beta-cells against endoplasmic reticulum stress in male mice. Endocrinology 2015, 156, 1242-1250. [CrossRef] [PubMed]

80. Cai, E.P.; Lin, J.-K. Epigallocatechin Gallate (EGCG) and Rutin Suppress the Glucotoxicity through Activating IRS2 and AMPK Signaling in Rat Pancreatic $\beta$ Cells. J. Agric. Food Chem. 2009, 57, 9817. [CrossRef]

81. Arya, A.; Yeng Looi, C.; Chuen Cheah, S.; Rais Mustafa, M.; Ali Mohd, M. Anti-diabetic effects of Centratherum anthelminticum seeds methanolic fraction on pancreatic cells, $\beta$-TC 6 and its alleviating role in type 2 diabetic rats. J. Ethnopharmacol. 2012, 144, 22-32. [CrossRef] [PubMed]

82. De la Puerta, R.O.; Domínguez, M.E.M.N.; Ruíz-Gutíerrez, V.; Flavill, J.A.; Hoult, J.R.S. Effects of virgin olive oil phenolics on scavenging of reactive nitrogen species and upon nitrergic neurotransmission. Life Sci. 2001, 69, 1213-1222. [CrossRef]

83. Kara, Y. Phenolic Contents and Antioxidant Activity of Jojoba (Simmondsia chinensis (Link). Schindler. Int. J. Sec. Metab. 2017, 4, 142-147. [CrossRef]

84. Brandes, R.P.; Kreuzer, J. Vascular NADPH oxidases: Molecular mechanisms of activation. Cardiovasc. Res. 2005, 65, 16-27. [CrossRef]

85. Wu, T.Y.; Khor, T.O.; Saw, C.L.; Loh, S.C.; Chen, A.I.; Lim, S.S.; Park, J.H.; Cai, L.; Kong, A.N. Anti-inflammatory/Anti-oxidative stress activities and differential regulation of Nrf2-mediated genes by non-polar fractions of tea Chrysanthemum zawadskii and licorice Glycyrrhiza uralensis. AAPS J. 2011, 13, 1-13. [CrossRef] [PubMed]

86. Lerma-García, M.; Herrero-Martínez, J.; Simó-Alfonso, E.; Mendonça, C.R.; Ramis-Ramos, G. Composition, industrial processing and applications of rice bran $\gamma$-oryzanol. Food Chem. 2009, 115, 389-404. [CrossRef]

87. Farese, R.V.; Sajan, M.P.; Standaert, M.L. Insulin-sensitive protein kinases (atypical protein kinase C and protein kinase B/Akt): Actions and defects in obesity and type II diabetes. Exp. Biol. Med. 2005, 230, 593-605. [CrossRef]

88. Choi, K.; Kim, Y.-B. Molecular mechanism of insulin resistance in obesity and type 2 diabetes. Korean J. Int. Med. 2010, 25, 119-129. [CrossRef]

89. Keane, K.N.; Cruzat, V.F.; Carlessi, R.; de Bittencourt, P.I., Jr.; Newsholme, P. Molecular Events Linking Oxidative Stress and Inflammation to Insulin Resistance and beta-Cell Dysfunction. Oxid. Med. Cell. Longev. 2015, 2015, 181643. [CrossRef]

90. Khodabandehloo, H.; Gorgani-Firuzjaee, S.; Panahi, G.; Meshkani, R. Molecular and cellular mechanisms linking inflammation to insulin resistance and beta-cell dysfunction. Transl. Res. 2016, 167, 228-256. [CrossRef]

91. Saxena, R.; Elbers, C.C.; Guo, Y.; Peter, I.; Gaunt, T.R.; Mega, J.L.; Lanktree, M.B.; Tare, A.; Castillo, B.A.; Li, Y.R.; et al. Large-Scale Gene-Centric Meta-Analysis across 39 Studies Identifies Type 2 Diabetes Loci. Am. J. Hum. Genet. 2012, 90, 410-425. [CrossRef]

92. Bhardwaj, P.; Khanna, D.; Balakumar, P. Catechin averts experimental diabetes mellitus-induced vascular endothelial structural and functional abnormalities. Cardiovasc. Toxicol. 2014, 14, 41-51. [CrossRef] [PubMed]

93. Wang, S.; Nie, S.; Zhu, F. Chemical constituents and health effects of sweet potato. Food Res. Int. 2016, 89, 90-116. [CrossRef] [PubMed]

94. Ayeleso, T.B.; Ramachela, K.; Mukwevho, E. Aqueous-Methanol Extracts of Orange-Fleshed Sweet Potato (Ipomoeabatatas) Ameliorate Oxidative Stress and Modulate Type 2 Diabetes Associated Genes in Insulin Resistant C2C12 Cells. Molecules 2018, 23, 2058. [CrossRef] [PubMed]

95. Huang, S.; Czech, M.P. The GLUT4 glucose transporter. Cell Metab. 2007, 5, 237-252. [CrossRef]

96. Kampmann, U.; Christensen, B.; Nielsen, T.S.; Pedersen, S.B.; Orskov, L.; Lund, S.; Moller, N.; Jessen, N. GLUT4 and UBC9 protein expression is reduced in muscle from type 2 diabetic patients with severe insulin resistance. PLoS ONE 2011, 6, e27854. [CrossRef]

97. Anderson, C.M.; Hu, J.; Barnes, R.M.; Heidt, A.B.; Cornelissen, I.; Black, B.L. Myocyte enhancer factor 2C function in skeletal muscle is required for normal growth and glucose metabolism in mice. Skelet. Muscle 2015, 5, 7. [CrossRef]

98. Schenk, S.; McCurdy, C.E.; Philp, A.; Chen, M.Z.; Holliday, M.J.; Bandyopadhyay, G.K.; Osborn, O.; Baar, K.; Olefsky, J.M. Sirt1 enhances skeletal muscle insulin sensitivity in mice during caloric restriction. J. Clin. Investig. 2011, 121, 4281-4288. [CrossRef] [PubMed] 
99. Price, N.L.; Gomes, A.P.; Ling, A.J.; Duarte, F.V.; Martin-Montalvo, A.; North, B.J.; Agarwal, B.; Ye, L.; Ramadori, G.; Teodoro, J.S.; et al. SIRT1 is required for AMPK activation and the beneficial effects of resveratrol on mitochondrial function. Cell Metab. 2012, 15, 675-690. [CrossRef]

100. Modi, S.; Yaluri, N.; Kokkola, T.; Laakso, M. Plant-derived compounds strigolactone GR24 and pinosylvin activate SIRT1 and enhance glucose uptake in rat skeletal muscle cells. Sci. Rep. 2017, 7, 17606. [CrossRef]

101. Huang, C.N.; Wang, C.J.; Yang, Y.S.; Lin, C.L.; Peng, C.H. Hibiscus sabdariffa polyphenols prevent palmitate-induced renal epithelial mesenchymal transition by alleviating dipeptidyl peptidase-4-mediated insulin resistance. Food Funct. 2016, 7, 475-482. [CrossRef]

102. Kim, D.; Han, G.D. Ameliorating Effects of Fermented Rice Bran Extract on Oxidative Stress Induced by High Glucose and Hydrogen Peroxide in 3T3-L1 Adipocytes. Plant Foods Hum. Nutr. 2011, 66, 285. [CrossRef]

103. Boue, S.M.; Daigle, K.W.; Chen, M.-H.; Cao, H.; Heiman, M.L. Antidiabetic Potential of Purple and Red Rice (Oryza sativa L.) Bran Extracts. J. Agric. Food Chem. 2016, 64, 5345-5353. [CrossRef]

104. Johnson, R.; Dludla, P.V.; Muller, C.J.; Huisamen, B.; Essop, M.F.; Louw, J. The Transcription Profile Unveils the Cardioprotective Effect of Aspalathin against Lipid Toxicity in an In Vitro H9c2 Model. Molecules 2017, 22, 219. [CrossRef] [PubMed]

105. Ooi, J.; Adamu, H.A.; Imam, M.U.; Ithnin, H.; Ismail, M. Polyphenol-rich ethyl acetate fraction isolated from Molineria latifolia ameliorates insulin resistance in experimental diabetic rats via IRS1/AKT activation. Biomed. Pharmacother. 2018, 98, 125-133. [CrossRef] [PubMed]

106. Cai, S.; Sun, W.; Fan, Y.; Guo, X.; Xu, G.; Xu, T.; Hou, Y.; Zhao, B.; Feng, X.; Liu, T. Effect of mulberry leaf (Folium Mori) on insulin resistance via IRS-1/PI3K/Glut-4 signalling pathway in type 2 diabetes mellitus rats. Pharm. Biol. 2016, 54, 2685-2691. [CrossRef] [PubMed]

107. Tucci, S.A.; Boyland, E.J.; Halford, J.C. The role of lipid and carbohydrate digestive enzyme inhibitors in the management of obesity: A review of current and emerging therapeutic agents. Diabetes Metab. Syndr. Obes. Targets Ther. 2010, 3, 125. [CrossRef]

108. Seymour, E.M.; Lewis, S.K.; Urcuyo-Llanes, D.E.; Tanone, I.I.; Kirakosyan, A.; Kaufman, P.B.; Bolling, S.F. Regular tart cherry intake alters abdominal adiposity, adipose gene transcription, and inflammation in obesity-prone rats fed a high fat diet. J. Med. Food 2009, 12, 935-942. [CrossRef]

109. Iwaki, M.; Matsuda, M.; Maeda, N.; Funahashi, T.; Matsuzawa, Y.; Makishima, M.; Shimomura, I. Induction of adiponectin, a fat-derived antidiabetic and antiatherogenic factor, by nuclear receptors. Diabetes 2003, 52, 1655-1663. [CrossRef]

110. Shao, Y.; Bao, J. Polyphenols in whole rice grain: Genetic diversity and health benefits. Food Chem. 2015, 180, 86-97. [CrossRef]

111. Hiemori, M.; Koh, E.; Mitchell, A.E. Influence of Cooking on Anthocyanins in Black Rice (Oryza sativa L. japonica var. SBR). J. Agric. Food Chem. 2009, 57, 1908-1914. [CrossRef]

112. Friedmsan, M. Rice brans, rice bran oils, and rice hulls: Composition, food and industrial uses, and bioactivities in humans, animals, and cells. J. Agric. Food Chem. 2013, 61, 10626-10641. [CrossRef] [PubMed]

113. Kim, S.M.; Rico, C.W.; Lee, S.C.; Kang, M.Y. Modulatory effect of rice bran and phytic acid on glucose metabolism in high fat-fed C57BL/6N mice. J. Clin. Biochem. Nutr. 2010, 47, 12-17. [CrossRef] [PubMed]

114. Jung, E.H.; Sung, R.K.; Hwang, I.K.; Tae, Y.H. Hypoglycemic effects of a phenolic acid fraction of rice bran and ferulic acid in C57BL/KsJ-db/db mice. J. Agric. Food Chem. 2007, 55, 9800-9804. [CrossRef] [PubMed]

115. Pinent, M.; Blay, M.; Blade, M.; Salvado, M.; Arola, L.; Ardevol, A. Grape seed-derived procyanidins have an antihyperglycemic effect in streptozotocin-induced diabetic rats and insulinomimetic activity in insulin-sensitive cell lines. Endocrinology 2004, 145, 4985-4990. [CrossRef] [PubMed]

116. Rhabasa-Lhoret, R.; Chiasson, J. International Textbook of Diabetes Mellitus; Wiley-Blackwell: Hoboken, NJ, USA, 2004; Volume 3, pp. 901-914.

117. Muller, C.J.; Joubert, E.; de Beer, D.; Sanderson, M.; Malherbe, C.J.; Fey, S.J.; Louw, J. Acute assessment of an aspalathin-enriched green rooibos (Aspalathus linearis) extract with hypoglycemic potential. Phytomed. Int. J. Phytother. Phytopharmacol. 2012, 20, 32-39. [CrossRef] [PubMed]

118. Ishak, N.A.; Ismail, M.; Hamid, M.; Ahmad, Z.; Abd Ghafar, S.A. Antidiabetic and hypolipidemic activities of curculigo latifolia fruit: Root extract in high fat fed diet and low dose STZ induced diabetic rats. J. Evid.-Based Complement. Altern. Med. 2013, 2013, 1-12. [CrossRef] [PubMed]

119. Rask-Madsen, C.; Kahn, C.R. Tissue-specific insulin signaling, metabolic syndrome, and cardiovascular disease. Arterioscler. Thromb. Vasc. Biol. 2012, 32, 2052-2059. [CrossRef] 
120. Wilson, R.D.; Islam, M.S. Effects of white mulberry (Morus alba) leaf tea investigated in a type 2 diabetes model of rats. Acta Pol. Pharm. 2015, 72, 153-160.

121. Perry, R.J.; Samuel, V.T.; Petersen, K.F.; Shulman, G.I. The role of hepatic lipids in hepatic insulin resistance and type 2 diabetes. Nature 2014, 510, 84-91. [CrossRef]

122. Kikuchi, A.; Takamura, T. Where does liver fat go? A possible molecular link between fatty liver and diabetes. J. Diabetes Investig. 2017, 8, 152-154. [CrossRef]

123. Snel, M.; Jonker, J.T.; Schoones, J.; Lamb, H.; De Roos, A.; Pijl, H.; Jazet, I.M. Ectopic Fat and Insulin Resistance: Pathophysiology and Effect of Diet and Lifestyle Interventions. Int. J. Endocrinol. 2012, 2012, 18. [CrossRef] [PubMed]

124. Sattar, N.; Gill, J.M.R. Type 2 diabetes as a disease of ectopic fat? BMC Med. 2014, 12, 123. [CrossRef] [PubMed]

125. Davis, P.A.; Yokoyama, W. Cinnamon intake lowers fasting blood glucose: Meta-analysis. J. Med. Food 2011, 14, 884-889. [CrossRef] [PubMed]

126. Cheng, D.M.; Kuhn, P.; Poulev, A.; Rojo, L.E.; Lila, M.A.; Raskin, I. In vivo and in vitro antidiabetic effects of aqueous cinnamon extract and cinnamon polyphenol-enhanced food matrix. Food Chem. 2012, 135, 2994-3002. [CrossRef] [PubMed]

127. Zhang, W.; Hong, D.; Zhou, Y.; Zhang, Y.; Shen, Q.; Li, J.-Y.; Hu, L.-H.; Li, J. Ursolic acid and its derivative inhibit protein tyrosine phosphatase $1 \mathrm{~B}$, enhancing insulin receptor phosphorylation and stimulating glucose uptake. Biochim. Biophys. Acta Gen. Subj. 2006, 1760, 1505-1512. [CrossRef] [PubMed]

128. Chen, C.-C.; Hsu, C.-Y.; Chen, C.-Y.; Liu, H.-K. Fructus Corni suppresses hepatic gluconeogenesis related gene transcription, enhances glucose responsiveness of pancreatic beta-cells, and prevents toxin induced beta-cell death. J. Ethnopharmacol. 2008, 117, 483-490. [CrossRef]

129. Collins, Q.F.; Liu, H.-Y.; Pi, J.; Liu, Z.; Quon, M.J.; Cao, W. Epigallocatechin-3-gallate (EGCG), a green tea polyphenol, suppresses hepatic gluconeogenesis through $5^{\prime}$-AMP-activated protein kinase. J. Biol. Chem. 2007, 282, 30143-30149. [CrossRef]

130. Hwang, J.-T.; Ha, J.; Park, I.-J.; Lee, S.-K.; Baik, H.W.; Kim, Y.M.; Park, O.J. Apoptotic effect of EGCG in HT-29 colon cancer cells via AMPK signal pathway. Cancer Lett. 2007, 247, 115-121. [CrossRef]

131. Robinson, K.A.; Stewart, C.A.; Pye, Q.N.; Nguyen, X.; Kenney, L.; Salzman, S.; Floyd, R.A.; Hensley, K. Redox-sensitive protein phosphatase activity regulates the phosphorylation state of $\mathrm{p} 38$ protein kinase in primary astrocyte culture. J. Neurosci. Res. 1999, 55, 724-732. [CrossRef]

132. Adamu, H.A.; Imam, M.U.; Ooi, D.-J.; Esa, N.M.; Rosli, R.; Ismail, M. In utero exposure to germinated brown rice and its oryzanol-rich extract attenuated high fat diet-induced insulin resistance in $\mathrm{F} 1$ generation of rats. BMC Complement. Altern. Med. 2017, 17, 67. [CrossRef]

133. Imam, M.U.; Azmi, N.H.; Bhanger, M.I.; Ismail, N.; Ismail, M. Antidiabetic Properties of Germinated Brown Rice: A Systematic Review. J. Evid.-Based Complement. Altern. Med. 2012, 2012, 1-12. [CrossRef] [PubMed]

134. Imam, M.U.; Ismail, M. Nutrigenomic effects of germinated brown rice and its bioactives on hepatic gluconeogenic genes in type 2 diabetic rats and HEPG2 cells. Mol. Nutr. Food Res. 2013, 57, 401-411. [CrossRef] [PubMed]

135. Jung, U.J.; Kim, H.J.; Lee, J.S.; Lee, M.K.; Kim, H.O.; Park, E.J.; Kim, H.K.; Jeong, T.S.; Choi, M.S. Naringin supplementation lowers plasma lipids and enhances erythrocyte antioxidant enzyme activities in hypercholesterolemic subjects. Clin. Nutr. 2003, 22, 561-568. [CrossRef]

136. Jung, U.J.; Lee, M.K.; Park, Y.B.; Kang, M.A.; Choi, M.S. Effect of citrus flavonoids on lipid metabolism and glucose-regulating enzyme mRNA levels in type-2 diabetic mice. Int. J. Biochem. Cell Biol. 2006, 38, 1134-1145. [CrossRef]

137. Do, G.-M.; Jung, U.J.; Park, H.-J.; Kwon, E.-Y.; Jeon, S.-M.; McGregor, R.A.; Choi, M.-S. Resveratrol ameliorates diabetes-related metabolic changes via activation of AMP-activated protein kinase and its downstream targets in db/db mice. Mol. Nutr. Food Res. 2012, 56, 1282-1291. [CrossRef] [PubMed]

138. Zulkawi, N.; Ng, K.H.; Zamberi, R.; Yeap, S.K.; Jaganath, I.B.; Satharasinghe, D.; Yong, C.Y.; Jamaluddin, A.B.; Tan, S.W.; Ho, W.Y. The in vivo hepato-recovery effects of the polyphenol-rich fermented food Xeniji ${ }^{\mathrm{TM}}$ on ethanol-induced liver damage. RSC Adv. 2017, 7, 38287-38299. [CrossRef]

139. Holt, M.P.; Cheng, L.; Ju, C. Identification and characterization of infiltrating macrophages in acetaminophen-induced liver injury. J. Leukoc. Biol. 2008, 84, 1410-1421. [CrossRef] 
140. Teresa Vanessa, F.; Annamaria, P.; Pengou, Z.; Franco, F. Hyperglycemia-induced Oxidative Stress and its Role in Diabetes Mellitus Related Cardiovascular Diseases. Curr. Pharm. Des. 2013, 19, 5695-5703. [CrossRef]

141. Les, F.; Carpéné, C.; Arbonés-Mainar, J.M.; Decaunes, P.; Valero, M.S.; López, V. Pomegranate juice and its main polyphenols exhibit direct effects on amine oxidases from human adipose tissue and inhibit lipid metabolism in adipocytes. J. Funct. Foods 2017, 33, 323-331. [CrossRef]

142. Banihani, S.; Swedan, S.; Alguraan, Z. Pomegranate and type 2 diabetes. Nutr. Res. 2013, 33, 341-348. [CrossRef]

143. Ekhlasi, G.; Shidfar, F.; Agah, S.; Merat, S.; Hosseini, A.F. Effects of Pomegranate and Orange Juice on Antioxidant Status in Non-Alcoholic Fatty Liver Disease Patients: A Randomized Clinical Trial. Int. J. Vitam. Nutr. Res. 2015, 85, 292-298. [CrossRef]

144. Xu, K.Z.-Y.; Zhu, C.; Kim, M.S.; Yamahara, J.; Li, Y. Pomegranate flower ameliorates fatty liver in an animal model of type 2 diabetes and obesity. J. Ethnopharmacol. 2009, 123, 280-287. [CrossRef]

145. Hontecillas, R.; O'Shea, M.; Einerhand, A.; Diguardo, M.; Bassaganya-Riera, J. Activation of PPAR $\gamma$ and $\alpha$ by Punicic Acid Ameliorates Glucose Tolerance and Suppresses Obesity-Related Inflammation. J. Am. Coll. Nutr. 2009, 28, 184-195. [CrossRef]

146. Furuhashi, M.; Saitoh, S.; Shimamoto, K.; Miura, T. Fatty Acid-Binding Protein 4 (FABP4): Pathophysiological Insights and Potent Clinical Biomarker of Metabolic and Cardiovascular Diseases. Clin. Med. Insights Cardiol. 2015, 8, 23-33. [CrossRef]

147. Anusree, S.S.; Priyanka, A.; Nisha, V.M.; Das, A.A.; Raghu, K.G. An in vitro study reveals the nutraceutical potential of punicic acid relevant to diabetes via enhanced GLUT4 expression and adiponectin secretion. Food Funct. 2014, 5, 2590-2601. [CrossRef]

148. Les, F.; Arbonés-Mainar, J.M.; Valero, M.S.; López, V. Pomegranate polyphenols and urolithin A inhibit $\alpha$-glucosidase, dipeptidyl peptidase-4, lipase, triglyceride accumulation and adipogenesis related genes in 3T3-L1 adipocyte-like cells. J. Ethnopharmacol. 2018, 220, 67-74. [CrossRef]

149. Woo, M.-S.; Choi, H.-S.; Seo, M.-J.; Jeon, H.-J.; Lee, B.-Y. Ellagic Acid Suppresses Lipid Accumulation by Suppressing Early Adipogenic Events and Cell Cycle Arrest. Phytother. Res. 2015, 29, 398-406. [CrossRef]

150. Laskin, D.L.; Sunil, V.R.; Gardner, C.R.; Laskin, J.D. Macrophages and tissue injury: Agents of defense or destruction? Annu. Rev. Pharmacol. Toxicol. 2011, 51, 267-288. [CrossRef]

151. Hussain, T.; Tan, B.; Yin, Y.; Blachier, F.; Tossou, M.C.; Rahu, N. Oxidative stress and inflammation: What polyphenols can do for us? Oxid. Med. Cell. Longev. 2016, 2016, 7432797. [CrossRef]

152. Du, C.; Shi, Y.; Ren, Y.; Wu, H.; Yao, F.; Wei, J.; Wu, M.; Hou, Y.; Duan, H. Anthocyanins inhibit high-glucose-induced cholesterol accumulation and inflammation by activating LXRalpha pathway in HK-2 cells. Drug Des. Devel. Ther. 2015, 9, 5099-5113. [CrossRef]

153. Wei, J.; Wu, H.; Zhang, H.; Li, F.; Chen, S.; Hou, B.; Shi, Y.; Zhao, L.; Duan, H. Anthocyanins inhibit high glucose-induced renal tubular cell apoptosis caused by oxidative stress in $\mathrm{db} / \mathrm{db}$ mice. Int. J. Mol. Med. 2018, 41, 1608-1618. [CrossRef]

154. Miranda-Diaz, A.G.; Pazarin-Villasenor, L.; Yanowsky-Escatell, F.G.; Andrade-Sierra, J. Oxidative Stress in Diabetic Nephropathy with Early Chronic Kidney Disease. J. Diabetes Res. 2016, 2016, 7047238. [CrossRef]

155. Yun, J.-M.; Jialal, I.; Devaraj, S. Epigenetic regulation of high glucose-induced proinflammatory cytokine production in monocytes by curcumin. J. Nutr. Biochem. 2011, 22, 450-458. [CrossRef]

156. Cordero-Herrera, I.; Chen, X.; Ramos, S.; Devaraj, S. (-)-Epicatechin attenuates high-glucose-induced inflammation by epigenetic modulation in human monocytes. Eur. J. Nutr. 2017, 56, 1369-1373. [CrossRef]

157. Kowluru, R.A.; Kanwar, M. Effects of curcumin on retinal oxidative stress and inflammation in diabetes. Nutr. Metab. 2007, 4, 8. [CrossRef]

(C) 2019 by the authors. Licensee MDPI, Basel, Switzerland. This article is an open access article distributed under the terms and conditions of the Creative Commons Attribution (CC BY) license (http://creativecommons.org/licenses/by/4.0/). 